Published in final edited form as:

Cytokine Growth Factor Rev. 2013 December ; 24(6): 485-501. doi:10.1016/j.cytogfr.2013.10.002.

\title{
Stemness of $\mathbf{T}$ cells and the hematopoietic stem cells: Fate, memory, niche, cytokines
}

\author{
Francesca B Aiello ${ }^{1,2}$, Laura Graciotti ${ }^{3}$, Antonio D Procopio ${ }^{3}$, Jonathan R Keller ${ }^{4}$, and Scott \\ K Durum ${ }^{1, *}$ \\ ${ }^{1}$ Laboratory of Molecular Immunoregulation, Frederick, MD 21702, USA. \\ ${ }^{2}$ Department of Medicine and Aging Sciences, University of Chieti-Pescara, 66013 Chieti, Italy \\ ${ }^{3}$ Department of Clinical and Medical Sciences, Marche Polytechnic University, 60100 Ancona, \\ Italy. \\ ${ }^{4}$ Laboratory of Cancer Prevention, Frederick, MD 21702, USA
}

\begin{abstract}
Stem cells are able to generate both cells that differentiate and cells that remain undifferentiated but potentially have the same developmental program. The prolonged duration of the protective immune memory for infectious diseases such as polio, small pox, and measles, suggested that memory $\mathrm{T}$ cells may have stem cell properties. Understanding the molecular basis for the life-long persistence of memory $\mathrm{T}$ cells may be useful to project targeted therapies for immune deficiencies and infectious diseases and to formulate vaccines. In the last decade evidence from different laboratories shows that memory $\mathrm{T}$ cells may share self-renewal pathways with bone marrow hematopoietic stem cells. In stem cells the intrinsic self-renewal activity, which depends on gene expression, is known to be modulated by extrinsic signals from the environment that may be tissue specific. These extrinsic signals for stemness of memory T cells include cytokines such as IL-7 and IL-15 and there are other cytokine signals for maintaining the cytokine signature (TH1, TH2 etc) of memory $\mathrm{T}$ cells. Intrinsic and extrinsic pathways that might be common to bone marrow hematopoietic stem cells and memory $\mathrm{T}$ lymphocytes are discussed and related to self-renewal functions.
\end{abstract}

\footnotetext{
"S.K.D.: (to whom correspondence should be addressed): Laboratory of Molecular Immunoregulation, FCRDC, Bldg 560, Frederick, MD 21702, USA. Tel: +1 301-846 1545; Fax: +1 301-846-6720; durums@ nih.mail.gov.

Author' contacts

F.B.A.: Laboratory of Molecular Immunoregulation, FCRDC, Bldg 560, Frederick, MD 21702, USA. Tel: +1 301-846 6283; Fax: +1 301-846-6720; aiellofb@nih.mail.gov, Department of Medicine and Aging Sciences, University of Chieti-Pescara, via dei Vestini, 66013 Chieti, Italy. Tel +39-0871-357399; Fax: 39-0871-540079; fbaiello@ unich.it

L.G.: Department of Clinical and Medical Sciences, Marche Polytechnic University, via Tronto 10, 60100, Ancona, Italy. Tel: +39 071-2206242; Fax: +39-071-2206103; 1.graciotti@univpm.it

A.D.P.: Department of Clinical and Medical Sciences, Marche Polytechnic University, via Tronto 10, 60100, Ancona, Italy. Tel: +39 071-2206241; Fax: +39071 2206103: a.d.procopio@univpm.it

J.R.K: Laboratory of Cancer Prevention, FCRDC, Bldg 560, Frederick, MD 21702, USA. Tel: +1 301-846-1461, Fax:

+1-301-846-6646, kellerjo@nih.mail.gov
}

Publisher's Disclaimer: This is a PDF file of an unedited manuscript that has been accepted for publication. As a service to our customers we are providing this early version of the manuscript. The manuscript will undergo copyediting, typesetting, and review of the resulting proof before it is published in its final citable form. Please note that during the production process errors may be discovered which could affect the content, and all legal disclaimers that apply to the journal pertain. 


\section{Keywords}

Hematopoietic stem cells; T memory stem cells; T memory cells; Stem cell markers; Self renewal

\section{1) Introduction}

A concept of "sternness" arises in modern discussions of embryonic stem cells, tissue stem cells and cancer stem cells, but many of its principles were discovered in hematology. Blood cell homeostasis has long been appreciated to require life long production of hematopoietic stem cells (HSC). As we will discuss here there is a similar life long persistence of memory $\mathrm{T}$ lymphocytes that is necessary to protect from infections. Long-term protective immune memory has been clearly demonstrated for measles, mumps, yellow fever, and polio. Noteworthy, CD4 and CD8 memory T cells specific for small pox antigens can be detected up to 75 years after vaccination (1). The hypothesis that memory B and T lymphocytes could have stem cell properties was formulated in 2001-2002 (2). It was inspired by the observation that the transcription factor Bcl-6, structurally similar to a repressor of neuronal differentiation in Drosophila, inhibits the expression of the transcription factor Blimp-1 which induces the differentiation of B cells in plasma cells and prevents B cell terminal differentiation (3). In keeping with this observation, Bcl-6 expression in lymphoid tissue is restricted to germinal center cells (4), and in memory B cells is 6-8 fold higher than in naive B cells (5). In 2002 transcriptional repressors of the Polycomb family, which regulate segmentation in Drosophila, were found to be expressed in hematopoietic stem cells (HSC) and in T cells (6). In HSC their expression declined with differentiation, but their functions were unknown (6).

Bone marrow HSC are distinguished on a functional basis. Cells transplanted into a lethally irradiated mouse that are able to sustain hematopoiesis over some months are defined as "long-term" HSC, whereas those that sustain hematopoiesis for no longer than three months are defined as "short-term" HSC. Long-term HSC give rise to short-term HSC which in turn give rise to multipotent progenitors without self-renewal potential (7). In 2006 gene expression profiles of HSC and T cells were compared. In memory T cells the transcripts differed from those observed in naive and effector cells, and in long-term HSC they differed from those of short-term HSC and multipotent progenitors. Interestingly, similar sets of transcripts were up or downregulated in HSC and memory T cells (8), suggesting similar gene expression profiles. These data reinforced the hypothesis that self-renewal of HSC and memory $\mathrm{T}$ cells might be regulated by shared signalling pathways. The aim of this review is to discuss these pathways. We hope that clarifying the mechanisms underlying the "stemness" of memory lymphocytes will improve protocols of vaccination and therapies for infectious disease, and have implications for diseases involving cells of the immune system.

Self-renewal is regulated by cell autonomous intrinsic factors (like transcription factors) and by extrinsic factors such as cytokines. There is a link between the extrinsic and the intrinsic arms of the process, for instance, when the expression of transcription factors is modulated by cytokines (9). HSC can undergo either "asymmetrical" or "symmetrical" division (10) Asymmetrical division generates one stem cell that remains undifferentiated and one 
daughter cell that differentiates, thus it does not change the stem cell number (10).

Symmetrical division generates two stem cells and may be required to increase the stem cell pool (10). It was hypothesized that the probability of asymmetrical division of hematopoietic cells could be influenced by cytokines (11) and by signals from cells present in the specific HSC microenvironment, termed the "niche" (12). In 2007 symmetrical and asymmetrical divisions were elegantly demonstrated to occur for HSC and signals from the microenvironment were shown to influence the pattern of division (13).

It is now clear that "self-renewal" of a stem cell is the result of multiple coordinated processes: proliferation, quiescence, survival, and maintaining the capacity to differentiate along a lineage. Memory T cells may share self-renewal pathways with long-term HSC, however there are pathways that can be reasonably expected to be different. For instance, HSC have to maintain an undifferentiated phenotype, while T lymphocytes need to retain the memory of the antigen and of their functional phenotype (Th1, Treg, etc), although plasticity of function appears to require that extrinsic signals maintain a functional phenotype. In the first part of this review the pathways regulating HSC self-renewal that may be also present in memory $\mathrm{T}$ cells will be described.

\section{Part I}

\subsection{HSC markers in bone marrow: "stem cell attire"}

Long-term HSC represent less than $0.5 \%$ of mouse bone marrow cells, thus the identification of a specific phenotype has been crucial for their isolation. There are differences between murine and human surface markers. Murine HSC express the stem cell factor receptor c-Kit, Thy-1(CD90), and stem cell antigen1 (Sca-1/Ly-6A), but not lineage markers ( Lin $^{-}$), thus they are frequently termed "KTLS" or "KLS" cells (14). KLS include long-term and shortterm HSC (14). Interestingly, Sca-1/Ly6A which belongs to the family of lymphocyte activation (Ly) proteins was originally identified as an antigen upregulated on activated lymphocytes (15). Sca-1, however, does not have a human ortholog (15). Murine, but not human HSC are CD38+ (14). Human HSC are Lin', and express c-Kit and Thy-1 (16).

CD34 is a type I transmembrane protein expressed by murine and human HSC. CD34 may play a role in cell-adhesion and lineage outcome $(14,17,18)$, and mast cells, megakaryocytes, endothelial cells and fibrocytes are variably positive $(14,17)$. Expression of CD34 declines with differentiation, however, it may also reflect the activation status of the cell, since it is inducible by G-CSF and fluouracil (14). Long-term HSC are CD34 lownegative in mice (19).

In humans HSC with long-term capability of self-renewal are CD34 positive (20). In addition, a rare CD34 negative population with a long-term capability of self-renewal even higher than that of CD34 positive HSC has been very recently described (21).

Human CD34+ HSC express CD44 (22), an integral membrane protein that in mice is a specific marker of memory $\mathrm{T}$ cells. (discussed in the second part of the review). CD44 exhibits multiple isoforms deriving from the utilization of different exons and from different post-translational modifications. These isoforms bind hyaluronic acid and variety of other 
molecules, such as extracellular matrix proteins, growth factors and adhesion molecules such as E selectin and L-selectin, expressed by endothelial cells and leukocytes, respectively (22). HSC CD44 is the most potent E selectin and L selectin ligand. Murine KLS, however, do not express CD44, thus, it has been difficult to study its role in vivo (22).

Human and murine long-term HSC express prominin or CD133, a pentaspan transmembrane molecule which is a useful marker, since both CD34 negative and positive cells are CD133+ (14). The signaling lymphocyte activating molecule SLAM (CD150) is selectively expressed by murine long-term HSC but not by multipotent progenitors (23). It belongs to the family of SLAM related receptors (SRR) that play a role in the maintenance of immunological memory $(1,24)$. CD150-deficient mice have normal hematopoiesis (23), this could indicate a non- essential role of CD 150 or redundant activities of other SRR. Anti-CD150 permits a great improvement of long-term HSC purification in mice. Human and murine bone marrow cells, however, display different SRR molecules, and human long-term HSC have been reported to be CD150 negative (25). Therefore CD150 in humans may not be a useful marker for improving purification of long-term HSC (26).

Finally, it has been recently found that human HSC coexpressing Thy- 1 and the adhesion molecule a 6 integrin (CD49f) which is not expressed by multipotent progenitors, were the most effective in long-term engraftment, and a single cell of this type could give rise to all hematopoietic lineages in vivo (27). Murine and human long-term HSC markers are summarized in Fig. 1.

\subsection{Pathways regulating proliferation}

A number of intrinsic and extrinsic pathways control the proliferative activity of HSC and some of them have been shown to operate in T cells. The most important intrinsic pathways are mediated by products of Polycomb-group ( $\mathrm{PcG}$ ) and Trithorax-group genes (28). These proteins form multimeric complexes that act on chromatin, regulating transcription of homeobox (Hox) genes. PcG products were identified in Drosophila as repressors of Hox genes, which encode transcription factors regulating body patterning and organogenesis (28). The 39 mammalian Hox genes are divided in 4 clusters (A-D) located on different chromosomes. Based on the sequence homology of the DNA binding homeodomain, the aligned genes are assigned to 13 groups defined as paralogs $(28,29)$. Hox gene function is necessary for the formation of the hematopoietic system, $(10,29)$ and HoxA9-deficient mice display impaired HSC proliferation (30).

Two PcG complexes, 1 and 2, have been identified and, impressively, members of both complexes participate in programs of self-renewal. At least 12 mammalian homologues of Drosophila proteins are members of PcG complex 1, including Bmi-1 and Mel-18 proteins (28). Bmi-1, highly expressed by mouse and human HSC, is necessary for maintenance of adult HSC and neural stem cells $(31,32)$. Bmi-1-deficient mice exhibit a hypocellular bone marrow with a markedly reduced number of long-term HSC (31). Bmi-1 represses the expression of the Ink4A locus products: the cell cycle inhibitor p16 ${ }^{\mathrm{INK} 4 \mathrm{a}}$, and $\mathrm{p} 19^{\mathrm{ARF}}$ which controls apoptosis through the tumor suppressor gene p53 $(33,34)$. Deletion of these genes, however, only partly reverses the self-renewal defect of Bmi-1-deficient stem cells (10, 33, 
34). Since Bmi-1 promotes many functions involved in self-renewal, it is reasonable that these two pathways are not sufficient to mediate all Bmi-1 effects.

Mel-18 is highly homologous to Bmi-1 (28), and since PcG proteins negatively regulate Hox genes, the expression of Hox genes was examined in Mel-18-deficient mice. Only the expression of HoxB4 was found to be markedly increased (35). This was associated with an increased number of HSC in the Go phase of the cell cycle with long-term reconstitution activity (35). Thus, Mel-18 is a negative regulator. More importantly, it has been found that embryonic stem cells transduced with HoxB4 or with mammalian paralog group 4 members (Hox A-D) acquire the capability to differentiate in HSC with long-term reconstitution activity $(29,36)$, and this observation may be of future clinical relevance.

The Mixed Lineage Leukaemia gene family of transcription factors comprises 5 members, MLL (also called MLL1) is the mammalian homologue of the Trithorax Drosophila gene and it is commonly rearranged in childhood leukaemia (10). It is required for the expression of multiple Hox genes (37). MLL-deficient mice die before embryonic day 17, and cells from the aorta-gonad-mesonephros region from these embryos, unlike the cells from control embryos, are unable to repopulate the bone marrow of irradiated mice (38). The function of MLL has been studied in conditional deletion models in murine fetuses and in adult mice. Fetal liver cells show a reduction in the number of long-term HSC, particularly in the quiescent fraction (39) and adult bone marrow cells show a reduced number of KSL, with inappropriate cell cycle entry and depletion of quiescent cells (40).

The Notch pathway also regulates expression of Hox genes during embryogenesis $(10,41)$. This extrinsic pathway is highly conserved throughout evolution, and controls self-renewal at different levels. Notch receptors and ligands are transmembrane proteins, thus signaling derives from cell-cell interactions. Notch signaling is essential for the generation of embryonic HSC and for T cell development $(42,43)$. It has been proposed that in adult bone marrow HSC Notch activation promotes proliferation and inhibits differentiation (10). For this reason this pathway will be discussed in the paragraph concerning the maintenance of stem cell identity.

The Wnt pathway also regulates Hox gene expression (41). In humans there are 19 secreted Wnt proteins that can bind 10 surface receptors of the Frizzled receptor family, which are homologous to G protein coupled receptors (44). Ligand-receptor interaction activates the cytoplasmic phosphoprotein protein Dishevelled (Dsh), a modular protein utilizing distinct domains to activate three pathways: the canonical, $\beta$-catenin dependent pathway, and the "non canonical" pathways. The non canonical pathways are so termed because they are $\beta$ catenin-independent $(44,45)$ and include the Planar Cell Polarity (PCP) and the Wnt/Ca ${ }^{2+}$ pathways. In the canonical pathway the binding of Wnt proteins to their receptors protects $\beta$-catenin from proteosomal degradation in the cytoplasm. B-catenin then translocates to the nucleus, forming a complex with transcription factors also expressed by $\mathrm{T}$ lymphocytes: $\mathrm{T}$ cell factors 1-4 (TCF-1-4) or Lymphoid-enhancer bindingl (Lef-1) $(44,45)$. These complexes activate Wnt downstream target genes. Wnt ligands are expressed by HSC and by bone marrow stromal cells suggesting both paracrine and autocrine signalling (41). Transduction of HSC with constitutively active $\beta$-catenin or stimulation with recombinant 
Wnt3A promotes HSC proliferation in vitro and increases expression of HoxB4 and Notch (46). Transgenic mice with activated $\beta$-catenin develop thymic lymphoma, and $\beta$-catenin activity promotes initiation and maintenance of cancer stem cells in myeloid chronic leukaemia (reviewed in 47). In agreement with these results, Wnt3A-deficient mice, which die prenatally, have reduced numbers of HSC in fetal liver with impaired long-term HSC function (48). Surprisingly, $\beta$-catenin- or $\beta$ - $\gamma$-catenin-deficient HSC exhibit normal hemopoiesis $(49,50)$, and enforced constitutive activation of $\beta$-catenin induces failure of hematopoiesis (41) and apoptosis of HSC (51). These results, apparently contrasting, may be explained by the observation that the Wnt3A-mediated canonical pathway is physiologically inhibited by the Wnt5A-mediated non-canonical pathway, which, for instance, causes decreased $\beta$-catenin expression (52). Another explanation may be that $\mathrm{Wnt} / \beta$-catenin promotion of HSC self-renewal may be predominantly intrinsic to stromal cells rather than HSC themselves (53). Wnt-mediated stromal signals are complex, they could promote an increase of HSC cell number (53), but also quiescence, and will be discussed in the section concerning quiescence.

Growth factors and cytokines produced from a variety of cells of the hematopoietic stem cell niche positively influence HSC proliferation: Stem cell factor (SCF), Thrombopoietin (TPO), FGF proteins, angiopoietin-like proteins, IGF-2, Flt-3 ligand and others (54). SCF is a major regulator of HSC self-renewal, promoting both proliferation and survival. SCF, alone or more effectively in combination with other cytokines, induces proliferation of fetal and adult HSC, and its receptor, c-Kit, is a tyrosine kinase $(55,56)$. SCF binding induces receptor homodimerization and cross-phosphorylation, creating docking sites for recruitment of other kinases, in particular, the p85 subunit of phosphatidylinisitol-3-kinase (PI3-Kinase) which partly mediates the proliferative signal (56). SCF also activates the Janus kinase 2 (Jak-2), and this is followed by phosphorylation of the transcription factors Stat 3 and Stat5A, known to positively regulate proliferation of murine and human HSC (55-57). In mature $\mathrm{T}$ cells the pathways induced by SCF are activated by other cytokines, and similarly promote proliferation and survival.

IL-10 exerts pleiotropic effects on T and B lymphocytes. Surprisingly, Lin ${ }^{-} \mathrm{Sca}-1+\mathrm{cKit}+$ cells express IL-10 receptor and were reduced in IL-10-deficient mice. IL-10 induced an increase of HSC number in short-term culture and HSC cultured on IL-10 secreting stroma display enhanced bone marrow repopulating activity (58). Thus, IL-10 has activities on both HSC and lymphocytes.

\subsection{HSC quiescence}

During early G1 phase, bone marrow HSC can exit from the cell cycle and enter a dormant, quiescent state termed the "G0" phase. In early studies it was shown that approximately $75 \%$ of murine KLS were quiescent and that 99\% of them divided on average every 57 days (59). Subsequently, the CD34-CD150+ fraction of murine KLS has been found to divide once every 145 days, corresponding to 5 division per mouse lifetime (60). Importantly, in mice treated with 5-FU or G-CSF these cells can enter the cell cycle and then switch to dormancy again (60). However, in serial transplantation, the ability to reconstitute the hematopoietic system eventually declines, and this loss of function is defined as "exhaustion" (reviewed in 
61). The cyclin-dependent kinase inhibitor $\mathrm{p} 21$ regulates the transition through the late G1 phase by inhibiting cyclin E-CDK2 complexes. In $\mathrm{p} 21^{-/}$mice there is a great reduction in the potential of reconstituting the hematopoiesis after serial transplantation and resistance to repeated administration of 5-FU is greatly reduced, and this is associated with a decrease of HSC in the G0 phase (61). In a different murine genetic background, however, p21 function is required only under condition of cellular stress (62). Thus, quiescence is important to prevent exhaustion due to stress induced proliferation. Quiescence can protect from acquiring mutations, from apoptosis and from "senescence", a state of permanent cell-cycle arrest (63). Last but not least, quiescence can also prevent differentiation, since proliferation is associated with commitment and differentiation. Mice deficient for growth factor independent-1 (Gfi-1) transcriptional repressor, or for the transcription factor E47, show reduced p21 expression and a phenotype similar to that of p-21-deficient mice 61, 64). E47deficient KLS show a 50\% decrease in p21 expression associated with hyperproliferation (64). In mammals E proteins (E47, E12, HEB and E2-2), belonging to the family of helixloop-helix transcription factors, can act as transcriptional activators or repressors depending on the cellular context (64). E47 and E12 (splice variants of the gene E2A) and HEB are expressed in T cells (65). Inhibitors of DNA binding (Id) proteins also display a helix-loophelix transcription domain and inhibit the transcriptional activity of E proteins forming with them inactive heterodymers (66). Id proteins have been recently shown to play an important role in memory $\mathrm{T}$ cell differentiation (discussed in part II). The role of Id proteins in HSC, however, is less clear. Loss of Id1 was associated, as expected, with an increased expression of p21 (66) but the number of cycling HSC was increased (66) and there were fewer longterm HSC (67). It was subsequently observed that Id1-deficient bone marrow cells developed normally in Id positive irradiated wild type mice, whereas HSC development was impaired in Id-deficient mice, indicating that the HSC defects were due to the microenviroment (68). Interestingly, in these mice stromal cells showed an altered cytokine production that could be at least partially responsible for the HSC defects (68).

The interactions of HSC with cells of the stem cell niche can induce quiescence. An important role of the Wnt-mediated pathway has been demonstrated using a paninhibitor of the canonical signalling. The protein Dickkopf1, produced by osteoblasts, blocks the binding of Wnt proteins with their receptors. Mice overexpressing Dickkopf1 in osteoblasts show reduced expression of p21 associated with an increased cycling of KLS cells and a decline in their hematopoietic reconstituting activity (69). Consistent with this result is the evidence that Wnt5A inhibits the activity of Wnt3A by increasing the percentage of HSC in G0 phase (52).

Low levels of reactive oxygen species (ROS) can maintain quiescence and block differentiation whereas high levels of ROS can induce HSC exhaustion through excess differentiation. The phosphoinositide 3-kinase (PI3K) pathway is critical for the activation of AKT, a family of serine-threonine kinases promoting survival in multiple cell types including lymphocytes. AKT 1 and 2 double deficient long-term HSC showed increased quiescence (cells in G0) accompanied by low levels of ROS, whereas artificially elevating ROS induced HSC differentiation in these cells (70). 
The transcription factors of the forkhead box (Fox) family are characterized by a forkhead or winged DNA binding domain and are divided in subfamilies based on their sequence homology $(71,72)$. The transcription factors of the $\mathrm{O}$ subfamily (Fox O 1, 3, 4 and 6 ) are regulated downstream the PI3K pathway. In quiescent cells they are localized into the nucleus, where they are hypophosphorylated and constitutively active. T cells express FoxO1, 3 and 4 (72). In FoxO3a-deficient mice HSC show elevation of ROS. The ROS effect, inducing differentiation, may in turn be mediated by activation of the mitogenactivated protein kinase (MAPK) p38 since inhibiting p38 MAPK improves the capability of HSC to form colonies in long-term cultures (73). The tumor suppressor gene Pten is a phosphatase which dephosphorylates PI3K, inactivating it (74). By inhibiting PI3K activity it acts indirectly, activating FoxO family members and therefore maintaining quiescence. Importantly, Pten is also a negative regulator of mammalian target of rapamycin complex 1 (mTORC1) which must be repressed to maintain quiescence in HSC (75).The mammalian target of rapamycin mTOR is a crucial regulator of multiple lymphocyte functions. It is a serine-threonine kinase existing in two multi-protein complexes mTORC1 and mTORC2, and its activation can occur via PI3K signaling (82). Its role in the generation of memory T cells will be discussed in the second part of the review.

\subsection{HSC survival}

Control of survival is essential for the homeostatic maintenance of HSC number, which is particularly important considering the limited life span of differentiated blood cells. A variety of intrinsic and extrinsic pathways protect HSC from apoptosis. The most studied intrinsic pathway is the mitochondrial apoptotic pathway, regulated by the anti-apoptotic Bcl-2 family members. The anti-apoptotic Bcl-2 family includes Bcl-2, Bcl-x, Bcl-w, Mcl-1 and other members that share regions of structural homology (Bcl-2 Homology Regions, or BH regions 1-4) (76). Early studies have shown that constitutive expression or overexpression of Bcl-2 enhances progenitor cell survival (reviewed in 77), and that mice lacking Bcl- $\mathrm{x}_{\mathrm{L}} / \mathrm{x}_{\mathrm{S}}$ undergo massive HSC death (78). Subsequently, it has been shown that inducible ablation of Mcl-1 results in non-viable HSC with failure of hematopoiesis (77). Extrinsic signals for survival of HSC and progenitor cells have been characterized in vitro to include cytokines. For instance SCF and IL3, which can act synergistically, were shown to sustain survival of $\operatorname{HSC}(56,79,80)$. IL-6 and Flt3 ligand also were able to promote HSC survival (Note that Flt3 is expressed by human but not by murine long-term HSC) (81). It is now clear that all these cytokines increase the expression of Bcl-2 family members. Mcl-1 RNA expression was inducible by SCF, IL-6 and Flt3 ligand, while Bcl-2 and Bcl- $\mathrm{x}_{\mathrm{L}}$ RNA expression was upregulated by IL-3 (82). Cytokine synergistic activity can thus be explained by their specific influences, and a number of observations support this hypothesis. In IL-3dependent hematopoietic cell lines IL-3 deprivation upregulates the protein level of the proapoptotic protein Bim whereas Bclx-L protein level is downregulated (83). SCF deprivation of KLS induces Bim and downregulates Bcl-2 mRNA, but does not affect Bcl-x. (84). IL-3 but not SCF increases Bcl-2 and Bcl-x protein expression in primary $\mathrm{Lin}^{-}$progenitor cells (82).

Another pathway important for survival is sustained by the intracellular serine protease inhibitors, called "ov-serpins" based on their homology with ovoalbumin. In early studies 
these enzymes were shown to be expressed in hematopoietic precursors and in mature peripheral blood cells (85). They inhibit the activity of serine proteases, or granzymes contained in cytotoxic granules, such as Granzyme B in cytotoxic $\mathrm{T}$ cells and protect from the apoptosis initiated by proteolysis $(85,86)$. Serpin (Spi) $2 \mathrm{~A}$ was shown to be expressed in a cell line commonly used as a model of hematopoietic stem cells and in hematopoietic progenitors (85). Differentiation induced downregulation of Spi2A mRNA expression whereas enforced expression was associated with increased quiescence (85). In later studies Spi2A has been shown to favour the long-term maintenance of memory $\mathrm{T}$ cells (87).

The PgC protein Bmi-1 contributes to the maintenance of mitochondrial integrity. In Bmi-1deficient mice there is accumulation of mitochondrial ROS, engagement of the DNA damage response (DDR) (88) and loss of viability (89). As noted previously, activation of p38MAPK in FoxO3-deficient mice is associated with loss of quiescence (73). In addition, activation of p38MAPK has been recently shown to induce KLS apoptosis and senescence in mice (90), but the mechanism leading to apoptosis has not been investigated. Interestingly, in memory $\mathrm{T}$ cells the apoptosis due to deprivation of the cytokine IL-7, which is essential for their survival, is mediated by the activation of p38MAPK, responsible for phosphorylating a protein inducing intracellular alkalinisation (91).

\subsection{Maintenance of stem cell identity: the mysterious undifferentiation of bone marrow HSC and the role of the niche.}

The Notch pathway is essential to maintain neural cell progenitors and to inhibit their differentiation. It also plays an essential role in T cell development (reviewed in 92). As previously mentioned Notch is required for the generation of HSC in the embryo whereas at later stages it determines lineage outcomes, including specification of lymphopoiesis (12, 93). There are studies supporting the hypothesis that Notch may promote proliferation of bone marrow HSC maintaining an undifferentiated phenotype. Importantly, however, in different types of Notch-signalling-deficient-mice, the number of bone marrow HSC is not decreased, indicating that this pathway is dispensable for HSC self-renewal (43). In mammals there are four Notch receptors (Notch1-4) and five structurally similar ligands: Delta-like 1, 2 and 3 and Jagged 1 and 2, that are single pass transmembrane proteins, thus, Notch signalling derives from cell-cell interaction (93). Osteoblasts in the stem cell niche and hematopoietic cells express both receptors and ligands, thus osteoblasts can signal osteoblasts and HSC, and HSC can signal HSC and osteoblasts (12).

Ligand binding induces cleavage in the extracellular domain and then in the transmembrane domain. The second cleavage is performed by the enzyme $\gamma$-secretase, which has two catalytic subunits, Presenilins 1 and 2. Following the second cleavage Notch intracellular domain (NICD) translocates into the nucleus, where in association with the transcriptional coactivator Mastermind like-1 (MAML-1) they convert the transcriptional repressor CBF-1 (also called RBPJ or CSL) in a transcriptional activator $(93,43)$. The target genes include the basic helix-loop helix transcription factors HES and their homologues HERP that, in general, function as transcriptional repressors and inhibit cell differentiation, although they can participate in other functions $(42,43)$. Other target genes, such as GATA3, CD25 and pre-Ta are involved in driving $\mathrm{T}$ cell development (42). The endocytosis of the ligands in 
endosomes by the signal-sending cell (before they are presented on the cell membrane) is necessary to activate signalling in the receiving cell $(12,42)$.This process is regulated by ubiquitination, and Mib-1 ubiquitin ligase is one of the key enzymes that regulate this process: Mib-1-deficient mice exhibit pan-Notch defects in development and organogenesis (42).

Early in vitro studies showed that constitutive activation of Notch resulted in the inhibition of granulocytic differentiation in a myeloid cell line (94). Activating Notch mutations are frequently found in human acute $\mathrm{T}$ cell lymphoblastic leukemia (42), and transplantation of bone marrow stem cells transduced with activated Notch induce development of T cell leukaemia in mice (95). Thus, to perform in vivo studies, KLS from RAG-1-deficient mice, which lack mature $\mathrm{T}$ and $\mathrm{B}$ cells, were transduced with activated Notch and transplanted into lethally irradiated C57BL/6 mice. In these mice the number of KLS was higher than that of mice transplanted with KLS carrying a control vector, while the number of differentiated granulocytic and erythroid cells was lower (96). KLS from the two groups of mice showed a similar cell cycle kinetics indicating an anti-differentiative rather than a proliferative effect (96). In addition, inhibition of CBF-1-dependent Notch pathways, obtained introducing in KLS a retroviral expression vector encoding for a CBF-1 dominant negative, resulted in a marked decrease of KLS and an increase of $\mathrm{Lin}^{+}$cells (97).

A role of the stem cell niche in Notch signalling was proposed. In mice expressing a constitutively active parathyroid hormone receptor in the osteoblastic lineage, osteoblasts upregulated Jagged-1. An increase in the number of both osteoblasts and HSC was observed, and HSC showed an elevated NICD level (98). However parathyroid hormone stimulates osteoblasts to produce multiple growth factors, not just Jagged-1, that are able to influenced HSC proliferation. The results subsequently obtained in Mib-1-deficient mice, however, have supported the concept. These mice, unable to transmit any Notch signal, develop a myeloproliferative disease (MPD) that eventually kills them. Surprisingly, MPD is not due to the absence of Notch signalling in KLS, because wild type KLS transplanted in these mice also undergo MPD despite being able to transmit and receive Notch signals. Thus, Notchdeficient niche cells support an abnormal HSC proliferation in the absence of a mutation in HSC, and a possible explanation is that niche cells are missing a Notch ligand (99).

Other studies have recently shown that Notch 2 is important for the generation of KLS at the expense of myeloid differentiation (100), and it has been demonstrated that KLS expanded by endothelial cells expressing multiple Notch ligands are able to reconstitute lethally irradiated mice (101). Thus, Notch signalling may promote bone marrow HSC proliferation and the maintenance of an undifferentiated phenotype. Nevertheless, the evidence that at least several components are dispensable for HSC self-renewal indicates that the physiological mechanisms keeping bone marrow HSC undifferentiated may be redundant or yet to be discovered.

We would like to conclude this part of the review emphasizing that all of the mentioned pathways may act in cooperation. The Wnt/ $\beta$-catenin and Pten/PI3K/AKT pathways have been recently shown to cooperate to drive long-term HSC expansion inducing proliferation, inhibiting apoptosis and blocking differentiation (51). In this case cooperation 
simultaneously influences more than one function to promote self-renewal. In Table 1 we have summarized the molecules involved in the different functions contributing to HSC selfrenewal with the related references.

\section{Part II}

\subsection{T memory cells and T memory stem cells}

The identification of markers distinguishing naïve from memory $\mathrm{T}$ cells is still an area of active research. Most markers are common to both mice and humans, but there are some differences between the species, and among CD4 and CD8 T cell subsets, likely attributable to their diversity in binding and functions.

The encounter of murine $\mathrm{T}$ cells with antigens results in a permanent expression of the adhesion molecule CD44 which persists when the T cells are transferred into antigen-free recipient mice (102). In mice a high CD44 expression is considered an accurate marker of memory, especially when used in conjunction with other markers. In humans naïve $\mathrm{T}$ cells express the high molecular weight isoform of the tyrosine phosphatase CD45 (CD45RA) while memory cells express the low molecular weight isoform (CD45RO), CD45RA however, can be re-expressed both by CD4 and by CD8 positive cells (102).

In humans memory $\mathrm{T}$ cells have been divided in two subsets: central $\left(\mathrm{T}_{\mathrm{CM}}\right)$ and effector $\left(\mathrm{T}_{\mathrm{EM}}\right)$ cells, based on the expression of two receptors: the lymphoid homing receptor $\mathrm{L}$ selectin, or CD62L, engaging vascular addressins, and CCR7, the receptor for the chemokine CCL21 (103). CD45RO ${ }^{+} \mathrm{CCR} 7^{+} \mathrm{CD}^{2} \mathrm{~L}^{+}$are defined as $\mathrm{T}_{\mathrm{CM}}$ This phenotypic distinction apply to $\mathrm{CD} 8^{+}$cells, since only about $30 \%$ of $\mathrm{CD} 4^{+}$memory cells is $\mathrm{CD} 62 \mathrm{~L}^{+}$ following polyclonal stimulation (104), and bone marrow $\mathrm{CD}^{+}$memory cells are $\mathrm{CD}^{4} \mathrm{~L}^{\star}$ (105). $\mathrm{T}_{\mathrm{CM}}$ home in secondary lymphoid organs and have little effector function $(102,103)$, but convert to effector cells after restimulation (106). $\mathrm{T}_{\mathrm{EM}}$ are found in inflamed peripheral tissue, they are CCR7 ${ }^{-} \mathrm{CD}^{-}{ }^{-}$and part of them expresses CD45RA (103). Their lifespan is shorter than that of $\mathrm{T}_{\mathrm{CM}}$ (107), and their number gradually decreases over time (108).

TEM produce IFN- $\gamma$, TNF and IL-2, and contain a high amount of perforin, thus, they can exert an immediate cytolytic function (102). $\mathrm{T}_{\mathrm{CM}}$ produce IFN $\gamma$, TNF and IL-2, but the amount of IL-2 is higher than that produced by $\mathrm{T}_{\mathrm{EM}}$ and is considered responsible for their high proliferative capability (102). Among human virus specific $\mathrm{CD} 8^{+}$cells TCM are perforin negative, while about one third of the TЕM are positive (108). Since naïve $\mathrm{T}$ cells are $\mathrm{CCR} 7^{+} \mathrm{CD} 62 \mathrm{~L}^{+}$, the absence of $\mathrm{CD} 45 \mathrm{RO}$ expression is used to distinguish them from TCM (102).

Different groups have shown in mice that the surface "killer cell lectin-like receptor G1" (KLRG-1), a receptor with inhibitory function expressed by natural killer (NK) cells, marks shortlived CD8 ${ }^{+}$effector T cells (109-111). KLRG-1 expression is inversely correlated with that of the receptor for the potent pro-survival cytokine interleukin-7 (IL-7R). KLRG-1 ${ }^{\text {high }}$ IL-7 ${ }^{\text {low }}$ cells are short-lived effector cells, whereas KLRG- ${ }^{\text {low }}$ IL-7 $\mathrm{R}^{\text {high }}$ cells, displaying long-term survival after the completion of the primary immune response, have been designated as memory precursor cells (109). These markers, thus, allow the isolation of 
$\mathrm{CD} 8^{+}$memory cells on a functional basis. In virus specific murine $\mathrm{CD} 4^{+} \mathrm{T}$ cells, however, a low expression of IL-7R by effector cells is transient, and not indicative of cells with short life span (112).

Murine and human memory $\mathrm{T}$ cells express the signalling lymphocyte activating molecule SLAM or CD150 (24). In mice deficient in the adaptor SAP, which mediates part of SLAM family member signalling, $\mathrm{CD} 4^{+} \mathrm{T}$ cells exhibit impaired adhesion to antigen presenting $\mathrm{B}$ cells and are not properly recruited in the germinal center (113).

The bone marrow is the niche of $\mathrm{CD}^{+}(114)$ and $\mathrm{CD} 4^{+}$memory $\mathrm{T}$ cells (105). Memory $\mathrm{T}$ cells co-localize with stromal cells expressing IL-7 $(105,115)$, suggesting that after their generation in secondary lymphoid organs they migrate to the bone marrow as the most appropriate location for homeostatic maintenance. $\mathrm{CD} 4^{+}$memory cells in bone marrow are $\mathrm{CD}_{4} 4^{+}$and their homing to bone marrow depends on the surface expression of a 2 integrin and Ly6C (105). Ly6C is also expressed by CD8 ${ }^{+}$memory cells (116).

Within the $\mathrm{T}_{\mathrm{CM}}$ population, is there a "memory stem cell" subset? Murine memory cells with stem cell properties showing, unexpectedly, a low CD44 expression have been identified within the murine $\mathrm{CD} 8^{+}$subset by two different laboratories. These cells, designated "T memory stem cells" ( $\mathrm{T}_{\mathrm{SCM}}$ ) are Sca-1/Ly6 $\mathrm{A}^{+}$(like HSC) and express high levels of Bcl-2 and CD122, the $\beta$ subunit common to IL-15 and IL-2 receptors (IL-2/ IL-15R $\beta)(117,118)$. Recently, the human $\mathrm{T}_{\mathrm{SCM}}$ counterpart has been characterized (119, 120). Human $\mathrm{T}_{\mathrm{SCM}}$ coexpress CD45RA and CD45RO (120) and are CCR7, CD62L and IL-7R positive $(119,120)$. In addition, they express CD95 (or Fas), known to be upregulated by naïve $T$ cells after T cell receptor (TCR) stimulation, and the IL-2/IL-15R $\beta$ (Fig. 2) (119, 120). Cytokines are crucial to generate human $\mathrm{T}_{\mathrm{SCM}}$. IL-7, $-15,-2,-4,-9$, and -21 belong to the $\gamma$ common $(\gamma-c)$ family of cytokines, so called because their receptors share the $\gamma$ chain, essential for signalling. IL-15 is required for $\mathrm{T}_{\mathrm{SCM}}$ expansion while IL-7 is critical to maintain the CD45RA ${ }^{+}$CD62L ${ }^{+}$phenotype (120). Thus, interestingly, IL-7 and IL-15 are non redundant, although they are both $\gamma$-c cytokines essential for memory $\mathrm{T}$ cell survival $(102,121)$. In association with IL-7, IL-2 can also support the expansion of $\mathrm{T}_{\mathrm{SCM}}$ but less effectively that IL-15. Murine and human $\mathrm{T}_{\mathrm{SCM}}$ exhibit self renewal ability and can generate TСм (117-120).

There is also some evidence for stem cell properties within the naïve $\mathrm{CD} 4^{+} \mathrm{T}$ population. A subset with very low CD44 expression has been recently found to be more efficient than $\mathrm{CD}^{+}$cells with low and intermediate $\mathrm{CD} 44$ expression in reconstituting the complete $\mathrm{CD}^{+}{ }^{+}$ $T$ cell pool when injected in severe combined immunodeficiency (SCID) mice (122). These cells show enhanced expression of Bcl-2 and IL-7R but behave as naive cells in terms of proliferation and IL-2 production (122).

\subsection{Development of immunological memory}

Memory lymphocytes provide important protection against infections. The frequency of memory $\mathrm{T}$ cells against specific pathogens is higher than in the naïve population, the response is more rapid and vigorous, and lasts longer (102). The primary immune response of naïve $\mathrm{T}$ cells against pathogens develops in 4 phases: priming, clonal expansion, 
differentiation of effector and regulatory $\mathrm{T}$ cells and contraction (102). Signals present at the time of priming crucially influence both expansion and differentiation. During priming $\mathrm{T}$ cells recognize antigen-derived peptides bound to MHC molecules on antigen-presenting cells (APC) by a specific T cell receptor (TCR) (signal 1). Expansion and differentiation result from the integration of signal 1 , plus signals provided by costimulatory membrane molecules (signal 2), and by cytokines produced by APC and responding T cells (signal 3). Different cytokines induce specific transcription factors and lead to chromatin remodelling and stable changes in gene expression which are necessary for appropriate differentiation. Effector cells generated by naïve $\mathrm{CD} 4^{+}$cells comprise five major T helper subsets: TH1, TH2, TH17, TH follicular and T regulatory cells. Effector cells generated by naïve CD8+ cells include cytotoxic and regulatory cells. Helper and cytotoxic cells cooperate to eliminate pathogens, while regulatory cells down regulate the activation of $\mathrm{T}$ cells and antigen presenting cells. Following the elimination of an antigen, effector cells undergo apoptotic death during the contraction phase, which restores the physiological cell number, so that $5-10 \%$ of the cells will survive as memory subsets (reviewed in 102).

It is debated as to which phase of the primary immune response generates the memory program, and there are several models for memory cell differentiation. The "linear" model proposes that memory cells derive from effector cells, thus, commitment to the memory phenotype would occur during the phase of contraction. (123-126). In contrast, according to the "asymmetric, divergent, or branched" model, memory cells would derive directly from naïve cells, in parallel to the effector cells but along a separate lineage, thus, commitment would occur during priming (127-130). The "progressive" model predicts that the signal strength, (TCR-MHC-peptide affinity, degree of costimulation and cytokine production) during the phase of priming would influence lineage commitment so that naïve cells receiving a strong signal would become effectors while those receiving a weak signal would become memory (131-133). Another model proposes that CD8+ memory cells would develop from the subset of cells defined as memory progenitor effector cells, KLRG-1 ${ }^{\text {low } I L-7 R ~}{ }^{\text {high }}$. These cells, capable of long-term survival, would not undergo contraction $(109,110)$.

Many results supporting each model have been produced, and, for example, two papers reporting data in favour of the linear (126) and the asymmetric (130) models were published in the same journal issue. The evidence that human $\mathrm{T}_{\mathrm{SCM}}$ challenged with antigen differentiate in $\mathrm{T}_{\mathrm{EM}}$ and $\mathrm{T}_{\mathrm{CM}}$ (120) could support a linear model, alternatively, naïve $\mathrm{T}$ cells may simultaneously generate $\mathrm{T}_{\mathrm{SCM}}, \mathrm{T}_{\mathrm{EM}}$ and $\mathrm{T}_{\mathrm{CM}}$ by asymmetric division. It has been shown that both $\mathrm{CD} 8^{+}$and $\mathrm{CD} 4^{+}$naïve TCR-transgenic $\mathrm{T}$ cells, are able to undergo asymmetric division, with a daughter cell displaying an effector profile and the other a memory profile (129). In addition, previous data indicated that a single naïve TCRtransgenic T cell transplanted into normal recipient mice, after TCR stimulation generated heterogeneous subsets of effector and memory cells (128). If we hypothesize that not only naïve cells can undergo asymmetric division all of these models might not be mutually exclusive. In support of this hypothesis, recent data show that $\mathrm{CD} 8^{+}$memory cells are capable of asymmetric division, producing two daughters resembling effector and central memory cells, respectively (134). 
In the following sections signalling molecules utilized by HSC and involved in the development of memory $\mathrm{T}$ cells will be considered.

\subsection{The powerful network of transcription factors: Tbet, Eomes, TCF, FoxO1, Ids, Bcl-6, Blimp1, Stat3}

Pathways relevant for the development of memory $\mathrm{T}$ cells have been identified during different phases of the primary immune response. Interestingly, transcription factors regulating quiescence in HSC are involved in the generation of memory T cells, perhaps because they operate in a different molecular context.

T-bet and Eomesodermin (Eomes) are members of the T-box family of transcription factors (135). It is well known that T-bet is essential for lineage commitment of $\mathrm{CD}^{+} \mathrm{T}$ helper 1 (TH1) cells (102). In $\mathrm{CD}^{+}$cells, T-bet and Eomes regulate cytolytic effector mechanisms, including the transcription of perforin and granzymes (135), and are responsible for the expression of IL-2/IL-15R $\beta$ (102). Responsiveness to IL-15 is required for CD8 ${ }^{+}$memory cell proliferation and survival, thus, T-bet and Eomes double deficient mice lack CD8 ${ }^{+}$ memory cells (102), and T-bet expression is inversely correlated with the generation of longlived memory CD8 ${ }^{+} \mathrm{T}$ cells (109).

Wnt proteins play a role in the generation of $\mathrm{CD} 8^{+}$memory $\mathrm{T}$ cells in part regulating the balance between T-bet and Eomes transcriptional activity. However, which Wnt pathway is involved is not clear. Naive T cells highly express TCF-1 and Lef-1, the transcription factors activated by Wnt proteins (136). TCF-1 expression is downregulated by antigen stimulation $(137,118)$, and subsequently upregulated during the transition of effectors in memory cells (136). TCF-1-deficient mice display a decrease of KLRG-1 ${ }^{\text {low }}$ IL-7 $\mathrm{R}^{\text {high }}$ memory precursor cells (138). Wnt3a induces Eomes expression via TCF (139), since TCF-1-deficient T cells show decreased Eomes expression (138). Eomes mediates some TCF effects since reintroduction of Eomes in TCF-1-deficient cells by a retroviral vector restores the expression of IL-2/IL-15R $\beta$ and improves cell viability, but does not completely reconstitute the pool of TCM, revealing the presence of other Wnt-TCF-dependent pathways (138). In memory T cells, as in HSC the role of $\beta$-catenin is controversial. After 4 days, in T cells primed in the presence of Wnt 3 there is no accumulation of $\beta$-catenin (140), and $\beta$-catenindeficient mice have no defects in memory $\mathrm{T}$ cell generation or function (139). Whether the structurally similar $\gamma$-catenin can compensate for the absence of $\beta$-catenin or there are other TCF-1 interacting intermediates is unknown. Nevertheless, during T cell priming in vitro, activation of the Wnt pathway using Wnt3a or an inhibitor of $\beta$-catenin degradation generates long-lived memory cells with high proliferative capacity and effector functions, and the capability to reconstitute immunodeficient hosts $(118,119)$. These $\mathrm{T}_{\mathrm{SCM}}$, described in the paragraph concerning memory cell markers are $\mathrm{CD} 8^{+} \mathrm{CD} 44^{\text {low }} \mathrm{CD} 62 \mathrm{~L}^{\text {high }} \mathrm{Sca}-1^{+}$ $\mathrm{IL} 7 \mathrm{R}^{+} \mathrm{IL}-2 / \mathrm{IL} 15 \mathrm{R} \beta^{+} \mathrm{Bcl}-2^{+}$in mice and CD45RA ${ }^{+} \mathrm{CCR} 7^{+}, \mathrm{CD} 2 \mathrm{~L}^{+} \mathrm{CD} 95^{+}, \mathrm{IL}^{-7 \mathrm{R}^{+}} \mathrm{IL}-2 /$ $\operatorname{IL} 15 R \beta^{+}$Bcl-2 $2^{+}$in humans $(118,119)$ (Fig.2). How the Wnt pathway drives the acquisition of self renewal capabilities is unclear; however it has also been proposed to confer stem cell like properties to TH17 cells (141). TheseTH17 cells, displaying the phenotype of terminally differentiated effector memory cells, (141-143) were expected to be short-lived (142). However, associated with high levels of TCF7 and $\beta$-catenin (141), they show in vivo long 
survival $(141,144)$ and increased proliferation (143). These findings are clinically relevant, because TH17 cells can exhibit a potent anti-tumor effect $(141,143)$ while, on the other hand, they contribute to the development of a variety of autoimmune diseases $(141,143$, 144).

The balance between T-bet (favouring short-lived KLGR-1 ${ }^{\text {high }}$ effector cells) and Eomes (favouring long_lived KLGR-1 ${ }^{\text {low }}$ memory precursor cells) is also regulated by the transcription factor FoxO1. FoxO1 can directly activate the Eomes promoter (145). As in HSC, in memory T cells FoxO1 activity is counteracted by PI3K and mTOR pathways. Phosphorylation of FoxO1 leads to its nuclear export and degradation and is dependent on AKT and mTORC2 kinase (72). mTORC1 kinase potentiates mTORC2 activity, degrading FoxO1, turning off Eomes and promoting T-bet mediated differentiation in short-lived effector cells (145). This supports previous results showing that inhibition of mTORC1 by rapamycin during the contraction phase accelerates the differentiation into KLGR-1 ${ }^{\text {low }}$ memory precursos cells (146). In vivo, a sustained AKT activity has been recently found to be associated with a reduction of $\mathrm{CD} 8^{+}$antigen specific $\mathrm{T}_{\mathrm{CM}}$, associated with phosphorylation of FoxO1 and mTOR kinase, along with elevated levels of $\mathrm{T}$ bet and decline of Eomes (147). Importantly, a reduced level of TCF-1 expression is observed in this setting, thus, AKT may be an upstream mediator of both mTORC1 kinase and Wnt proteins (147).

Control of survival by E proteins and their inhibitory Id proteins profoundly affects memory cell generation Id 2 promoting $\mathrm{T}_{\mathrm{EM}}$, whereas Id 3 promotes $\mathrm{T}_{\mathrm{CM}}$. In early studies it was found that Id2-deficient mice exhibited normal spleen and CD4/CD8 $\mathrm{T}$ cell ratio, but lymph nodes were absent (148). In these mice, following normal priming and proliferation, there was a defect in the formation of the TЕм subset, due to an increased rate of apoptosis during the phase of contraction (149). This was associated with increased expression of BimEL and decreased expression of Bcl-2 and Serpinb9 (also termed "Spi6") (149). It is now clear, from elegant in vivo studies, that Id 2 and Id 3 control the survival of distinct memory CD8 T cell subsets. CD $8^{+} \mathrm{T}$ cells with high expression of Id 3 generate KLRG-1 ${ }^{\text {low }}$ long-lived memory precursor cells, (149) whereas $\mathrm{CD}^{+}{ }^{+} \mathrm{Id} 3$ deficient cells, although able to proliferate in response to antigenic stimulation, undergo increased contraction and fail to generate them $(149,150)$. Comparison of cells with high and low expression of Id 3 has revealed that the set of genes regulated by Id3 overlaps with genes with known E2A occupancy in T cells, (149).

The comparison of Id 3 positive versus negative cells has shown that the genes regulated by Id3 are implicated in DNA replication and repair, and differ from those involved in Id2mediated control of survival (150). Most importantly, in this study Id3 is identified as one of the targets of the transcription factor Blimp-1 (150). As mentioned in the introduction, the transcriptional repressor Bcl-6 in germinal center B cells prevents the expression of Blimp-1, thus inhibiting plasma cell terminal differentiation (3). Bcl-6 is expressed by activated CD8 ${ }^{+}$ T cells (151) and expression of Blimp-1 is inducible by TCR stimulation and cytokines (9). Since Bcl-6 and Blimp-1 mutually repress each other in B and in T cells (9), they were both hypothesized to regulate the generation of memory cells. In keeping with this hypothesis, in Bcl-6-deficient mice the percentage of splenic $\mathrm{CD} 8^{+} \mathrm{CD} 44^{+} \mathrm{IL}-2 / \mathrm{IL} 15 \mathrm{R} \beta^{+} \mathrm{T}$ cells is decreased while it is increased in Bcl-6 transgenic mice (reviewed in 9). Blimp-1 plays the opposing role: murine Blimp-1-deficient $\mathrm{CD} 8^{+}$cells primarily develop as KLRG1 ${ }^{\text {low }}$ 
IL-7 $\mathrm{R}^{\text {high }}$ memory precursor cells whereas the number of KLRG1 $1^{\text {high }} \mathrm{IL}-7 \mathrm{R}^{\text {low }}$ short-lived effector cells is severely reduced. $(152,153)$. The results showing that Blimp-1 directly binds the promoter of Id 3 in CD8+ effector T cells and represses its activity (150) suggest that the phenotype observed in Blimp-1 deficient mice is due the unrestricted activity of Id3.

Cytokines influence the transition from effectors to memory cells regulating the expression of transcription factors and /or protecting cells from apoptosis $(109,149,150,154-156)$, and, as previously discussed, IL-7 and IL-15 are both required to generate human $\mathrm{T}_{\mathrm{SCM}}$ (120).

IL-10 has been shown to promote HSC self renewal. The first two studies investigating whether IL-10 affected the generation of memory cells showed contrasting results (157, 158). Recent work, however, shows that in mice lacking both IL-10 and IL-21 (but not IL-10 or IL-21 alone) the ability to clear a primary infection is normal, but the formation of KLRG-1 ${ }^{\text {low }}$ memory precursor cells is severely reduced, (159). Both IL-10 and IL-21 activate Stat-3, and Stat-3-deficient mice display a phenotype similar to that of IL-10/IL-21 double deficient mice. Moreover, Stat-3-deficient $\mathrm{CD} 8^{+}$cells have reduced expansion and life span, and reduced Eomes, Bcl-6 and Blimp-1 expression (159). Therefore Stat 3 integrates different extrinsic signals and regulates the activity of several members of a transcription factor network.

\subsection{Homeostatic vs antigen-driven proliferation of memory T cells: IL-7, IL-15 and Notch}

In addition to the rapid proliferation in response to recall antigens, memory $\mathrm{T}$ cells, like naïve T cells, undergo a periodic cell division termed "homeostatic proliferation" (HP). This type of proliferation contributes to maintaining a stable cell number. HP of naïve T cells requires contact of TCR with self peptides/MHC and the presence of IL-7 $(102,107)$. Naïve cells have an extremely low rate of HP $(107,120)$. For naïve T cells, TeM and TCM the rates of proliferation are approximately $0.2 \%, 4.7 \%$, and $1.5 \%$ per day, with an intermitotic time of 1 year, 15 and 48 days, respectively (107). $\mathrm{HP}$ of $\mathrm{CD} 4^{+}$and $\mathrm{CD} 8^{+}$memory cells does not require TCR/self peptide /MHC contact, but IL-7 and IL-15 are essential both for proliferation and survival $(102,121)$.

In lymphopenia, CD8+ naïve T cells markedly increase the rate of HP and a significant proportion of them acquire the phenotype of memory cells although they have not recognized a foreign antigen. This process of HP-induced expansion $(102,160)$ generates cells called "memory-like" (161) or "memory phenotype" cells (160). These HP-induced memory-like cells are effective against infections, although less than antigen-induced memory cells (162). It has been recently found that HP-induced expansion requires the IL-7 dependent activation of the mTOR kinase, which is in turn associated with increased T-bet expression (162). This is followed, as previously mentioned, by sensitization to IL-15 due to increased expression of IL-2/IL-15R $\beta$. Interestingly, mTOR kinase silencing blocks T-bet expression but not the generation of memory phenotype $\mathrm{T}$ cells since it enhances the expression of Eomes. (162).

TCR-dependent proliferation of memory cells is dependent on Bcl-6. In Bcl-6-deficient mice $\mathrm{CD}^{+}$memory $\mathrm{T}$ cell proliferation in vivo, following antigen stimulation, is lower than in 
wild type mice (reviewed in 9). Similar results have been observed studying $\mathrm{CD} 4^{+}$memory cells (163). As mentioned in the previous paragraph, Stat-3 may be one of the upstream molecules in this pathway (159).

The PcG protein Bmi-1, essential for HSC proliferation, also promotes proliferation of naïve and memory $\mathrm{T}$ cells $(164,165)$. Bmi-1 deficient mice were known to display an altered $\mathrm{T}$ cell development and reduced $\mathrm{T}$ cell number (6). It was subsequently demonstrated that stimulation with OVA antigen increased Bmi-1 expression by transgenic OVA specific naïve $\mathrm{CD}^{+}$cells and that silencing or overexpression of Bmi- 1 in $\mathrm{T}$ cells caused reduction and increased proliferation, respectively (164). Among $\mathrm{CD} 8^{+} \mathrm{CD}_{4} 4^{+} \mathrm{T}$ cells KLRG1-, but not $\mathrm{KLRG}^{+}$, cells increased Bmi-1 expression after TCR stimulation. Following a polyclonal stimulus KLRG1 ${ }^{+}$cells proliferated poorly, and this was associated with an increased level of mRNA encoding the cell cycle inhibitors p16 and p19. Since Bmi-1 represses p16 and p19 expression, its low expression in KLRG1 ${ }^{+}$cells was proposed to account for their poor proliferation. (164). In a different setting these results have been recently confirmed (165).

The effect of Notch ligands Jagged 1 and Delta-Like 4 has been studied on effector and memory cells in mice responding to antigens generating Th1 or Th2 responses. Jagged 1 increases proliferation of effector cells in both Th1 and Th2 conditions. However, Delta-like 4 increases Th 2 but not Th1 driven proliferation of memory cells and, interestingly, two observations have suggested that Notch proliferative effects are mediated by Bmi-1: 1) the expression of Bmi-1 in naïve T cells stimulated in the presence of Delta-like 4 is higher than in its absence 2) the transcriptional factor RBPJ, acting downstream Notch ligands, binds Bmi-1 promoter and its binding increases when TCR stimulation occurred in the presence of Delta-like 4 (165).

\subsection{Pathways regulating quiescence: there is one more reason for $\mathrm{T}$ cells to maintain quiescence}

T cell "exhaustion" is a progressive functional unresponsiveness which occurs in chronic infections. In severe infections exhausted cells can also undergo physical deletion, mainly by apoptosis (166). Although $\mathrm{T}$ cell exhaustion is observed under conditions of antigen persistence it is not yet clear whether it can be considered a loss of quiescence caused by excessive proliferation, as it is for HSC exhaustion. X-linked lymphoproliferative (XLP) syndrome results from mutations in the SLAM associated protein SAP, the adaptor which partly mediates the signalling of SLAM family members (24). In XLP the excessive early proliferation of $\mathrm{CD} 8^{+}$cells following EBV infection has been hypothesized to cause a subsequent marked decrease in the replicative capacity (167).

For T lymphocytes there is another reason to be quiescent: prevention of autoimmunity. The abrogation of $\mathrm{T}$ cell quiescence is observed in mice harbouring $\mathrm{CD} 4^{+}$cells deficient for the transcription factor Runx-1, who develop a fatal lung autoimmune disease (168) and also in patients at high risk for multiple sclerosis (169).

Information about quiescence of $\mathrm{T}$ cells is scanty. Recently, the status of chromatin condensation (170), Fox factors and mTORC1 kinase activity, have been shown regulate quiescence of naïve T cells (171). How quiescence is maintained in memory T cells is still 
unknown. However, a mechanism underlying their readiness to undergo proliferation upon a secondary challenge has been elucidated. The interaction between CD27, a TNF receptor family member expressed by T cells, and its ligand CD70 on dendritic cells maintains memory $\mathrm{T}$ cells in the G1 phase of the cell cycle, so that deprivation of dendritic cells reverts memory T cells from the G1 to the G0 phase (172). As already mentioned, activation of the PI3 kinase-Akt pathway leads to phosphorylation of FoxO1, its release from DNA, and translocation to the cytoplasm and degradation, and this is followed by cell cycle progression $(71,72)$. T cell stimulation with an antibody recognizing CD27 results in Akt phosphorylation and in phosphorylation and translocation of FoxO1 from the nucleus to the cytoplasm (172). In keeping with these results, in CD27-deficient mice the majority of memory $\mathrm{T}$ cells after a recall viral infection are in G0 while in wild type mice they are in G1 (172). This state of "readiness" may enable a fast secondary response to pathogens. We observed that $\mathrm{CD} 44^{+}$cells from lymph nodes of mice treated with IL-7 produced high levels of IFN- $\gamma$ (173). If the cells were sorted as $\mathrm{CD}^{+} \mathrm{CD}^{+} 4^{+}$cells, however, IFN- $\gamma$ was not detected, suggesting that $\mathrm{CD}_{4} 4^{+} \mathrm{CD}^{-}$cells were dendritic cells, necessary to sustain IFN- $\gamma$ production. (Aiello FB, Durum S unpublished results).

It has been recently proposed that after infections undergo resolution the remaining low doses of antigens induce a state of dormancy in $\mathrm{CD}^{+}$memory $\mathrm{T}$ cells. Whether this could be considered as an induction of quiescence has yet to be demonstrated (174).

\subsection{Memory T cell protection from apoptosis by IL-7 and IL-15: Bcl-2 family, Spi, IEX-1, Bmi-1}

After differentiation memory cells surviving the phase of contraction are protected for longterm survival by IL-7 and IL-15 $(102,121)$, that are essential for the generation and persistence of human $\mathrm{T}_{\mathrm{SCM}}(120)$. These $\boldsymbol{\gamma}$-c cytokines regulate the mitochondrial pathway of apoptosis regulating the expression and the activity of anti-and pro-apoptotic Bcl-2 family members. Relevant anti-apoptotic members include Bcl-2 itself, Mcl-1 and Bcl- $\mathrm{x}_{\mathrm{L}}$. Proapoptotic members include Bim, Bax, Bad, Puma and Noxa.

T cells with Mcl-1 conditional deletion show marked spontaneous and activation-induced apoptosis (175), and Mcl-1 is required for survival of CD4 and CD8 naïve and memory T cells (176). IL-7 upregulates Bcl-2, Mcl-1 and Bcl- $\mathrm{x}_{\mathrm{L}}$ expression in memory T cells (176, 177). The upregulation of Bcl-2 is mediated by the transcriptional activity of phosphorylated Stat-5 (121, 178), and constitutive activation of Stat-5 enhances survival and homeostatic proliferation of $\mathrm{CD}^{+}$effector and memory $\mathrm{T}$ cells (179). In addition, it has been recently shown that IL-7R-deficient thymocytes undergo telomere erosion, which leads to DNA damages responses, p53-dependent apoptosis and chromosome abnormalities (180). Perhaps the protection of genomic stability may partly explain the IL-7-mediated preservation of the $\mathrm{T}_{\text {SCM }}$ phenotype (120). IL-15 upregulates Bcl-2 expression in memory T cells in vivo (181) and is a potent inducer of Mcl-1 expression in T cells (176). In addition, it inhibits the expression of the pro-apoptotic protein Bim (181) which is important for memory cell survival (182).

Suppression of Bim by IL-15 in NK cells was shown to be mediated by the PI3-kinase pathway, which leads to the inactivation of FoxO3 (183). A recent study demonstrates that in 
FoxO3-deficient mice, after LCMV infection, virus specific CD8 ${ }^{+}$cells accumulate in the spleen, and the number of both KLRG-1 ${ }^{\text {high }}$ short-lived effectors and KLGR ${ }^{\text {low }}$ long-lived memory precursor cells increases due to reduced apoptosis. FoxO3-deficient memory cells show reduced expression of Bim and do not undergo apoptosis when deprived of IL-15 (184). Thus, as in HSC, specific influences on different Bcl-2 family members might explain why more cytokines, even belonging to the same family, are necessary for survival. Besides Bim, FoxO3 controls the expression of additional genes regulating apoptosis, such as Fasligand and TRAIL, and cell cycle, such as p27, Cyclin B and others (185). Noteworthy, in $\mathrm{CD}^{+} \mathrm{T}_{\mathrm{CM}}$ the level of FoxO3 phosphorylation is more than two fold higher than in TEM, and this correlates well with their better survival and with a higher expression of FoxO3 target genes in Tем. (186).

The intracellular serine protease inhibitors Serpins (Spi), also expressed by HSC, are important for memory cell survival at multiple levels. The expression of Spi2A is inducible by IL-7 and IL-15 (87). Spi2A-deficient mice after LCMV infection show a normal number of $\mathrm{T}_{\mathrm{CM}}$ immediately after infection, but there is an impairment in the long-term maintenance of memory cells which is worsened by reinfections. This is associated with decreased homeostatic proliferation and survival (87). Importantly, the number of virus specific memory cells can be restored by cathepsin B deficiency, since Spi2A inhibits cathepsin B driven lysosomal permeabilization (87). Spi6 also protects $\mathrm{CD} 8_{+}$cytotoxic $\mathrm{T}$ cell from apoptosis by inactivating Granzyme B (86). Spi6-deficient mice show a normal number of memory cells, however the number of memory cells following a secondary challenge is markedly decreased, suggesting the occurrence of self inflicted apoptosis (187).

The role of the immediate early response gene X 1 (IEX-1), expressed by long-term HSC and memory T lymphocytes (8) is still poorly understood. IEX-1 is inducible by stress and cytokines (TNF, TPO), and in different conditions it can either induce or inhibit survival (188). In murine T cells, activation increases its expression, and its decline correlates with susceptibility to apoptosis (189). IEX-1 transgenic mice accumulate T cells with an altered phenotype in the spleen and in lymph nodes, and develop a lupus-like autoimmune disease (189). IEX-1-deficient mice display a decreased survival of $\mathrm{CD}^{+} \mathrm{TH}^{-1}$ cells, associated, however, with an increased number of TH17 cells and severe arthritis after collagen immunization. (190). High levels of ROS can cause mitochondrial membrane disruption and apoptosis (191), and one of the mechanisms underlying IEX-1 anti-apoptotic activity is the reduction of mitochondrial ROS production (192). In addition, IEX-1 interacts with Mcl-1 (193), and controls its nuclear localization when Mcl-1 participates to the DNA damage response (194). In 293T cells IEX-1 overexpression induces apoptosis, and this requires the presence of Bim (193). It is unclear how IEX-1 acts in memory T cells. It is also unclear whether IEX-1 modulates HSC survival, although CD34+ bone marrow cells from patients affected by myelodysplastic syndrome frequently show rearrangements and altered expression of IEX-1 $(195,196)$.

The Polycomb group protein Bmi-1 is important for survival of CD4 ${ }^{+}$memory T cells (197). In its absence TH1 and TH2 effectors develop normally. However, when Bmi-1-deficientOVA-specific transgenic cells are adoptively transferred into nu/nu mice there is a dramatic enhancement of apoptosis during the secondary response and a severe decrease in the 
number of TH2 memory cells. Bmi-1-deficient TH2 effector and memory cells show increased expression of p16Ink4A and p19ARF mRNA, and of mRNAs encoding for Bax, Puma, Noxa and other pro-apoptotic molecules (197). Thus, in T cells as in HSC, Bmi-1 suppresses the Ink4A locus, and in $\mathrm{T}$ cells the suppression of Noxa expression is responsible for protection from apoptosis.

Bmi-1 suppression of Noxa expression in T cells has been linked to histone modifications that regulate the functional activity of chromatin. Methylation of specific lysine residues in histones at regulatory regions such as promoters and enhancers can maintain chromatin domains as constitutive heterochromatin, or control whether genes can be activated or silenced (198). In particular, histone H3 methylation of lysine 9 and 27 is associated with gene silencing whereas methylation of lysine 4 , which can be observed in combination with acetylation of lysine 9 and 14, is associated with active chromatin domains (198). The CpG methylation of DNA is a chromatin modification well known to promote gene silencing (198). In TH1 and TH2 effectors the binding of Bmi-1 to the Noxa gene is associated with tri-methylation of histone 3 at lysine 27 (H3-K27) resulting in silencing. In addition, a DNA methyltransferase methylates Noxa DNA at CpG islands, in a Bmi1-dependent manner (198). Thus Noxa is inhibited by both histone and DNA modifications.

\subsection{Pathways that maintain the identity of memory T cells: IL-4, Gata-3, Trithorax and PgC}

HSC need to live "forever" remaining undifferentiated. In contrast, memory T cells need to maintain a differentiated phenotype, useful to fight specific pathogens. Therefore, the pathways utilized by HSC and memory T cells to maintain their identity could be reasonably expected to be different. Nevertheless, molecules utilized by HSC in various pathways of self renewal are utilized by $\mathrm{T}$ cells to keep their functional identity.

The development of different identities in effector cells (TH1, TH2, TH17 etc.) after the first encounter with an antigen has been thoroughly investigated, but only a few studies have been performed about the maintenance of subset identity in memory cells. These mainly concern TH2 cells. TH 2 cells, involved in humoral immunity and allergic reactions, produce IL-4, IL-5 and IL-13. TCR engagement in the continuous presence of IL-4 is required for their differentiation and this is defined as a TH2-skewing condition (102). IL-4 induces the activation of Stat-6, which upregulates the transcription factor GATA3 (102), required for differentiation $(199,200)$.

As previously mentioned, the hyperacetylation of histones is known to characterize an open chromatin status, with increased accessibility of promoters and enhancers to transcription factors. A week after TCR stimulation in the presence of IL-4 a selective hyperacetylation of histone $\mathrm{H} 3$ and $\mathrm{H} 4$ at the IL-4 promoter and enhancer is observed (201). This is Stat6 dependent, as it does not occur in Stat6-deficient cells (201). Other studies have subsequently found that GATA3 is required for hyperacetylation of histone $\mathrm{H} 3$ (H3K9-14) at the IL-5 promoter and for maintaining unmethylated CpG sites in IL-4 intron 2 DNA (202). In addition, they identify, at previously examined regulatory regions of IL-4 and IL-13 loci, a pattern of histone $\mathrm{H} 3$ methylation in lysine 4, which in combination with the acetylation of lysine 9 and 14 is associated with active chromatine domains $(202,203)$. 
Effector and memory cells display similar levels of $\mathrm{H} 3$ hyperacetylation and lysine 4 methylation at the regulatory regions of the IL- $4,-5$ and -13 genes. However in memory cells, TCR engagement by a recall antigen no longer requires IL-4 to maintain the chromatin status to produce IL-4, IL-5 and IL-13, and to express a high level of GATA3 mRNA. (203). Which mechanism accounts for this difference? The answer to this question has been obtained studying the long-term maintenance of GATA3 expression in memory T cells. As mentioned in the first part of the review in HSC PcG and Trithorax group proteins regulate the chromatin status, and exert opposing effects on the transcription of Hox genes (204).

MLL is a member of the Trithorax protein family with histone methyltransferase activity and it specifically methylates lysine 4 in histone H3 (204). Moreover, MLL can form a protein complex containing RNA Polymerase II (Pol II), and specific sites in IL-4 and IL-13 promoters were previously found to bind Pol II (203). GATA3 locus expression is regulated by two promoters, one distal (1a) and one proximal (1b) to the coding exons (205). Onodera et al have demonstrated that in naive T cells a PcG complex containing Bmi-1 is bound upstream to $1 \mathrm{~b}$, concomitantly with a pattern of histone $\mathrm{H} 3$ lysine 27 methylation (associated with silencing) (206). In contrast, a Trithorax complex, formed by MLL and the protein Menin, is bound downstream of this promoter up to exon 2, concomitantly with H3 methylation in lysine 4 (206). Menin is the product of the tumor suppressor gene Men1, and is essential for DNA binding of the complex (207). Following TCR stimulation in the presence of IL-4 the PgC complex dissociates from DNA and this is accompanied by decreased lysine 27 histone $\mathrm{H} 3$ methylation whereas the Trithorax complex now binds the whole GATA 3 locus, and this is associated with increased lysine 4 histone $\mathrm{H} 3$ methylation (Fig. 3) (207). Remarkably, the same group demonstrates that the Trithorax complex is not necessary for the development of normal effector cells, but is essential for the maintenance of the TH2 phenotype in memory cells. Since MLL-deficient mice are embryonic lethal, they utilize MLL ${ }^{+/-}$TH2 memory cells, which in contrast to MLL $^{+/+}$cells, following TCR stimulations in the absence of IL- 4 are not able to produce TH2 cytokines, to maintain the chromatin status at IL-4 and IL-13 gene regulatory regions, and to upregulate GATA3 mRNA (208).

More recently, Nakata et al have identified two other components in the Trithorax complex, clarifying another important issue (209). GATA3 is known to activate its own transcription leading to increased IL-4 production. Thus, it exerts an important positive feed-back (210). In developing thymocytes the transcription factor cMyb binds GATA3 (211). Nakata et al have detected cMyb and GATA3 itself within the Trithorax complex and found that they act cooperatively to activate the GATA3 promoter (209). In addition they find Menin to be essential for cMyb-GATA3 binding and $\mathrm{cMyb}$ to be important to obtain the expected chromatin modifications at the GATA3 locus (209). These data clarify the mechanism of GATA3 autoactivation. Since lysine 4 methylation by MLL is required for recruitment of Pol II (212) a temporal sequence for the transcriptional initiation may be hypothesized (Fig. 3).

The role of PgC complexes in the maintenance of a memory phenotype is less clear than Trithorax components. Mel-18-deficient mice die within 6 weeks after birth (213). Mice with a partial deficiency of Mel-18 display an impaired IL-4 production by TH2 cells associated with a low degree of demethylation at the IL-4 locus and low GATA3 mRNA 
expression (214). It has been recently demonstrated that during the development of TH1 and TH2 effector cells PcG complex proteins (Mel-18, Ezh2, Eed, Ring1A) bind the cytokine signature genes (IL-4 promoter in TH2, IFN- $\gamma$ promoter in TH1 cells) and enhance their transcription (215). This is also observed in memory TH cells. These data were unexpected, since PcG complexes are considered repressors. Moreover, Mel-18 did not increase IFN- $\gamma$ transcription through chromatin modification, but rather by facilitating binding of the transcription factors T-bet and NFAT1 to the IFN- $\gamma$ promoter. An important observation is that all these PcG proteins repress Hoxa7 gene expression in both TH1 and TH2 cells (215). Hox genes play a crucial role in HSC self renewal. Stimulation with PHA upregulates Hox B gene expression in naive human $\mathrm{T}$ cells, and treatment with antisense oligonucleotides for Hox B2 or B4 decreases PHA induced proliferation (216). The expression of a number of Hox genes belonging to all 4 groups (A-D) has been assessed in unstimulated and polyclonally stimulated naïve CD4+ and CD8+ T cells (217). Whether Hox genes play a role in memory $\mathrm{T}$ cell self renewal, however, is at presently unknown.

In Table 2 we have summarized the molecules involved in the different functions contributing to memory $\mathrm{T}$ cell self renewal and the related references.

\section{Conclusions}

"Stemness" results from the integration of several functions, proliferation, quiescence and survival, thus we have attempted to compare pathways involved in HSC and memory T cell self renewal on a functional basis. $T$ cell subset identity is an additional property that distinguishes memory T cells from HSC. Proliferation is controlled by several pathways in HSC and memory T cells, and many are similar, perhaps underscoring the importance of regulating this function at multiple levels.

Quiescence mechanisms in memory $\mathrm{T}$ cells are unclear, but the available observations suggest that they might be similar to those of HSC. Survival (anti-apoptotic) mechanisms of memory T cells and HSC are similar in terms of downstream mechanism, although different upstream factors control them. $\mathrm{T}$ cell subset identity appears to be maintained in memory cells by reciprocal interactions between transcription factors acting concomitantly with epigenetic modifications. These identity mechanisms are cell type specific, and many questions, including the biochemical distinction between temporary and permanent repressive mechanisms are still open (218). Although there are more publications concerning CD8+ than CD4+ memory T cells, the mechanisms maintaining cell identity have been mostly studied in CD4+ TH2 cells, thus how the identity of the other helper subsets including Treg, Th17 and the newly identified subsets of innate lymphocytes that are important cytokine producers remain to be investigated.

Adoptive $\mathrm{T}$ cell therapy based on the transfer of specific anti-viral or anti-tumor $\mathrm{T}$ cells into affected patients has shown efficacy and safety, and is increasingly exploited.

Transfer of $\mathrm{T}_{\mathrm{SCM}}$ or of anti-tumor specific TH17 cells with stem cell properties displaying the highest degree of proliferation and survival may markedly improve the results of adoptive cell therapy in clinical trials. 
Thus, a comprehensive understanding of memory $\mathrm{T}$ cell self renewal may shape future vaccination protocols and tailored therapeutic strategies for infectious diseases as well as suggesting therapeutic strategies for autoimmunity and immunodeficiency.

\section{References}

1). Gourley TS, Wherry EJ, Masopust D, Ahmed R. Generation and maintenance of immunological memory. Semin Immunol 2004;16:323-333. [PubMed: 15528077]

2). Fearon DT, Manders P, Wagner SD. Arrested differentiation, the self renewing memory lymphocyte and vaccination. Science 2001;293:248-250. [PubMed: 11452114]

3). Reljic R, Wagner SD, Peakman LJ, Fearon DT. Suppression of signal transducer and activator of transcription 3-dependent B lymphocyte terminal differentiation by BCL-6. J Exp Med 2001;1841-1848.

4). Flenghi L, Ye BH, Fizzotti M, Bigerna B, Cattoretti G, Venturi S, Pacini R, Pileri S, Lo Coco F, Pescarmona E, Pelicci PG, Dalla Favera R, Falini B. A specific monoclonal antibody (PG-B6) detects the expression of the BCL-6 protein in germinal center B cells. Am J Pathol 1995;147: 405-11. [PubMed: 7639334]

5). Krag Kjeldsen M, Perez-Andres M, Schmitz A, Johansen P, Boegsted M, Nyegaard M, Gaihede M, Bukh A, Johnsen HE, Orfao A, Dybkaer K. Multiparametric flow cytometry for identification and fluorescence activated cell sorting of five distinct B cell subpopulation in normal tonsil tissue. Am J Clin Pathol 2011;136:960-69. [PubMed: 22095383]

6). Jacobs JJ, van Lohuizen M. Polycomb repression: from cellular memory to cellular proliferation and cancer. Biochim Biophys Acta. 2002;1602:151-61. [PubMed: 12020801]

7). Morrison SJ, Wandycz AM, Hemmati HD, Wright DE, Weissman IL. Identification of a lineage of multipotent hematopoietic progenitors. Proc Natl Acad Sci USA 1997;94:1908-1913. [PubMed: 9050878]

8). Luckey CJ, Bhattacharya D, Goldrath AW, Weissman IL, Benoist C, Mathis D. Memory T and memory B cells share a transcriptional program of self-renewal with long-term hematopoietic stem cells. Proc Natl Acad Sci U S A 2006;103:3304-3309. [PubMed: 16492737]

9). Nutt SL, Kallies A, Belz GT. Blimp-1 connects the intrinsic and the extrinsic regulation of T cell homeostasis. J Clin Immunol 2008;28:97-106. [PubMed: 18071884]

10). Zon L. Intrinsic and extrinsic control of hematopoietic stem-cell self renewal Nature 2008;453:306-313. [PubMed: 18480811]

11). Takano H, Ema H, Sudo K, Nakauchi H. Asymmetric division and lineare commitment at the level of hematopoietic stem cells: inference from differentiation in daughter cell and granddaughter cell pairs. J Exp Med 2004;199:295-302. [PubMed: 14744992]

12). Blank U, Karlsson G, Karlsson S. Signaling pathways governing stem-cell fate. Blood 2008;111:492-503. [PubMed: 17914027]

13). Wu M, Kwon HY, Rattis F, Blum J, Zhao C, Ashkenazy R Jackson TL, Gaiano L, Oliver T, Reya T. Imaging hematopoietic precursor division in real time. Cell Stem Cell 2007;1:541-554. [PubMed: 18345353]

14). Ratajczak MZ. Phenotypic and functional characterization of hematopoietic stem cells. Curr Opin Hematol 2008;15:293-300. [PubMed: 18536565]

15). Holmes C, Stanford WL. Concise review: stem cell antigen-1: expression, function, and enigma. Stem Cells 2007;25:1339-13347. [PubMed: 17379763]

16). Murray L, DiGiusto D, Chen B, Chen S, Combs J, Conti A, Galy A, Negrin R, Tricot G, Tsukamoto A. Analysis of human hematopoietic stem cell populations. Blood Cells 1994;20:364-370. [PubMed: 7538340]

17). Nielsen J, McNagny M. CD34 is a key regulator of hematopoietic stem cell trafficking to bone marrow and mast cell progenitor trafficking in the periphery. Microcirculation 2009;16:487-496. [PubMed: 19479621] 
18). Salati S, Zini R, Bianchi E, Testa A, Mavilio F, Manfredini R, Ferrari S. Role of CD34 antigen in myeloid differentiation of human hematopoietic cells. Stem Cells 2008;26:950-959. [PubMed: 18192237]

19). Osawa M, Hanada K, Hamada K, Nakauchi H. Long-term lymphohematopietic reconstitution by a single CD34-low-negative hematopoietic stem cell. Science 1996;273:242-245. [PubMed: 8662508]

20). Okuno Y,Ywasaki H, Huettner CS, Radomska HS, Gonzales DA, Tenen DG, Akashi K. Differential regulation of the human and murine CD34 genes in hematopoietic stem cells. Proc Natl Acad Sci USA 2002;99:6246-6251. [PubMed: 11983914]

21). Anjos-Afonso F, Currie E, Palmer HG, Foster KE, Taussig DC, Bonnet D. CD34(-) Cells at the Apex of the Human Hematopoietic Stem Cell Hierarchy Have Distinctive Cellular and Molecular Signatures. Cell Stem Cell. 2013;13:161-174. [PubMed: 23910083]

22). Sackstein R. The biology of CD44 and HCELL in hematopoiesis: the 'step 2-bypass pathway' and other emerging perspectives. Curr Opin Hematol. 2011;18:239-248 [PubMed: 21546828]

23). Kiel MJ, Ylmaz OH, Cox T, Morrison S. SLAM family receptors distinguish hematopoietic stem and progenitor cells and reveal endothelial niches for stem cells. Cell 2005;121:1109-1121. [PubMed: 15989959]

24). Bhat R, Eissmann Pn Endt J, Hoffmann S, Watzl C. Fine-tuning of immune responses by SLAMrelated receptors. J Leukoc Biol 2006;79:417-424. [PubMed: 16365151]

25). Sintes J, Romero X, Marin P, Terhorst C, Endel P. Differential expression of CD150 (SLAM) family receptors by human hematopoietic stem and progenitor cells. Exp Hematol 2008;36:1199_ 1204. [PubMed: 18495325]

26). Larochelle A, Savona M, Wiggins M, Anderson S, Ichwan B, Keyvanfar K, MorrisonS J, Dunbar CE. Human and rhesus macaque hematopoietic stem cells cannot be purified based only on SLAM family markers. Blood 2011;117:1550-1554. [PubMed: 21163926]

27). Notta F, Doulatov S, Laurenti E, Poeppl A, Jurisica I, Dick J E. Isolation of single human hematopoietic stem cells capable of long term multilineage engraftment. Science 2011;333:218221. [PubMed: 21737740]

28). Takihara Y, Hara J. Polycomb-group genes and hematopoiesis. Int J Hematol 2000;72:165-172. [PubMed: 11039664]

29). Iacovino M, Hernandez C, Xu Z, Bajwa G, Prather M, Kyba M. A conserved role for hox paralog group 4 in regulation of hematopoietic progenitors. Stem Cell Dev 2009;18:783-792.

30). Lawrence HJ, Christensen J, Fong S, Hu YL, Weissman I, Sauvageau G, Humphries RK,Largman C. Loss of expression of the Hoxa-9 homeobox gene impairs the proliferation and repopulating ability of hematopoietic stem cells. Blood 2005;106:3988-3994. [PubMed: 16091451]

31). Park IK, Qian D, Kiel M, Becker MW, Pihalja M, Weissman IL, Morrison SJ, Clarke MF. Bmi-1 is required for maintenance of adult self-renewing haematopoietic stem cells. Nature 2003;423:302-305. [PubMed: 12714971]

32). Molofsky AV, Pardal R, Iwashita T, Park IK, Clarke MF, Morrison SJ. Bmi-1 dependence distinguishes neural stem cell self-renewal from progenitor proliferation. Nature 2003;425:962967. [PubMed: 14574365]

33). Jacobs JJ, Kiebom K, Marino S, Depinho RA, van Lohuizen M. The oncogene and Polycomb group gene Bmi-1 regulates cell proliferation and senescence through the ink4A locus. Nature 1999;397:164-168. [PubMed: 9923679]

34). Iwama A, Oguro H, Negishi M, Kato Y, Morita Y, Tsukui H, Ema H, Kamijo T, Katoh-Fukui Y, Koseki H, van Lohuizen M, Nakauchi H. Enhanced self-renewal of hematopoietic stem cells mediated by the polycomb gene product Bmi-1. Immunity 2004;21:843-851. [PubMed: 15589172]

35). Kajiume T, Ninomiya Y, Ishihara H, Kanno R, Kanno M. Polycomb group gene mel-18 modulates the self-renewal activity and cell cycle status of hematopoietic stem cells. Exp Hematol 2004;32:571-578. [PubMed: 15183898]

36). Lee GS, Kim BS, Sheih JH, Moore M. Forced expression of Hox-B4 enhances hematopoietic differentiation by human embryonic stem cells. Mol Cells 2008;4:487-493. 
37). Yu BD, Hess JL, Horning SE, Brown GA, Korsmeyer SJ. Altered Hox expression and segmental identity in Mll-mutant mice. Nature. 1995;378:505-508. [PubMed: 7477409]

38). Ernst P, Fisher JK, Avery W, Wade S, Foy D, Korsmeyer SJ. Definitive hematopoiesis requires the mixed-lineage leukemia gene Dev Cell 2004;6:437-43

39). McMahon KA, Hiew SY, Hadjur S, Veiga-Fernandes H, Menzel U, Price AJ, Kioussis D, Williams O, Brady HJ. Mll has a critical role in fetal and adult hematopoietic stem renewal. Cell Stem Cell 2007;1:338-345. [PubMed: 18371367]

40). Jude C D, Climer L, Diyong Xu, Artinger E, Fisher J, Ernst P.Unique and independent role for MLL in adult hematopoietic stem cells and progenitors. Cell Stem Cell 2007;1:324-337 [PubMed: 18371366]

41). Campbell C Risueno RM, Salati S, Guezguez B, Bhatia M Signal control of hematopoietic stem cell fate: Wnt, Notch and Hedgehog as the usual suspect Curr Opin Hematol 2008;15:319-325. [PubMed: 18536569]

42). Bigas A, Espinosa L. To be or Notch to be. Blood 2012;119:3226-35. [PubMed: 22308291]

43). Pajcini KV, Speck NA, Pear WS. Notch signaling in mammalian hematopoietic stem cells. Leukemia 2011; 25:1525-1532. [PubMed: 21647159]

44). Komiya Y, Habas R. Wnt signal transduction pathways. Organogenesis 2008;4:68-75. [PubMed: 19279717]

45). Staal FJT, Luis TC. Wnt signaling in hematopoiesis: crucial factors for self-renewal, proliferation, and cell fate decisions. J Cell Biochem 2009;109:844-849.

46). Reya T, Duncan A W, Allies L, Domen J, Scherer D, Willert K, Hintz L, Nusse R, Weissman IL. A role for Wnt signaling in self-renewal of hematopoietic stem cells. Nature 2003;423:409-414. [PubMed: 12717450]

47). Lento W, Congdon K, Voermans C, Kritzik M, Reya T. Wnt signaling in normal andmalignant hematopoiesis. Cold Spring Harb Perspect Biol. 2013;5:a008011. [PubMed: 23378582]

48). Luis TC, Weerkamp F, Naber BA, Baert MR, de Haas EF, Nikolic T, Heuvelmans S, De Krijger RR, van Dongen JJ, Staal FJ. Wnt3a deficiency irreversibly impairs stem cell selfrenewal and leads to defects in progenitor cell differentiation. Blood 2009;15:546-554.

49). Cobas M, Wilson A, Ernst B, Mancini SJC, MacDonald RH, Kemler R, Radtke F. Beta-catenin is dispensable for hematopoiesis and lymphopoiesis. J Exp Med 2004;199:221-229. [PubMed: 14718516]

50). Koch U, Wilson A, Cobas M, Kemler R, Macdonald HR, Radtke F. Simultaneous loss of beta- and gamma-catenin does not perturb hematopoiesis or lymphopoiesis.Blood. 2008 1 1;111:160-164. [PubMed: 17855627]

51). Perry JM, He XC, Sugimura R, Grindley JC, Haug JS, Ding S, Li L. Cooperation between both $\mathrm{Wnt} / \beta$ catenin and PTEN/PI3K/Akt signaling promotes primitive hematopoietic stem cell selfrenewal and expansion. Genes Dev 2011; 25:1928-1942. [PubMed: 21890648]

52). Nemeth MJ, Topol L, Anderson SM, Yang Y, Bodine DM. Wnt5a inhibits canonical Wnt signaling in hematopoietic stem cells and enhances repopulation. Proc Natl Acad Sci USA 2007;104:15436-15441. [PubMed: 17881570]

53). Oh IH. Microenvironmental targeting of Wnt/b-catenin signals for hematopoietic stem cell regulation.Exp Opin Biol Ther 2010; 10:1315-1329.

54). Lymperi S, Ferraro F, Scadden D. The HSC niche has turned 31 Has our knowledge matured? Ann N Y Acad Sci 2010; 1192:12-18. [PubMed: 20392212]

55). Kent D, Copley M, Benz C, Dykstra B, Bowie M, Eaves C. Regulation of hematopoietic stem cells by the steel factor/KIT signaling pathway. Clin Cancer Res 2008;14:1926-1930. [PubMed: 18381929]

56). Lennartson J, Jelacic T, Linnekin D, Shivakrupa R. Normal and oncogenic forms of the receptor tyrosine kinase Kit. Stem Cells. 2005;23:16-43. [PubMed: 15625120]

57). Schepers H, van Gosliga D, Wierenga AT, Eggen BJ Schuringa Jj, Vellenga E. STAT5 is required for long term maintenance of normal and leukemic human stem/progenitor cells Blood 2007;110:2880-2888. [PubMed: 17630355] 
58). Kang YJ, Yang SJ, Park G, Cho B, Min CK, Kim TY, Lee JS, Oh IH. A novel function of interleukin-10 promoting self-renewal of hematopoietic stem cells. Stem Cells 2007;25:18141822. [PubMed: 17464085]

59). Cheshier SH, Morrison SJ, Liao X, Weissman IL. In vivo proliferation and cell cycle kinetics of long-term self-renewing hematopoietic stem cells. Proc Natl Acad Sci U S A 1999;96:31203125. [PubMed: 10077647]

60). Wilson A, Laurenti E, Oser G, van der Wath RC, Blanco-Bose W, Jaworski M, Offner S, Dunant CF, Eshkind L, Bockamp E, Lió P, Macdonald HR, Trumpp A. Hematopoietic stem cells reversibly switch from dormancy to self-renewal during homeostasis and repair. Cell 2008;135:1118-1129. [PubMed: 19062086]

61). Orford KW, Scadden DT. Deconstructing stem cell self-renewal: genetic insights into cell-cycle regulation. Nat Rev Genet 2008;9:115-128. [PubMed: 18202695]

62). van Os R, Kamminga LM, Ausema A, Bystrykh LV, Draijer DP, van Pelt K, Dontje B, de Haan G. A Limited role for $\mathrm{p} 21 \mathrm{Cip} 1 / \mathrm{Waf} 1$ in maintaining normal hematopoietic stem cell functioning. Stem Cells 2007;25:836-843. [PubMed: 17170062]

63). Gil J, Peters G. Regulation of the Ink4a tumour suppressor locus: all for one or one for all Nature Rev Mol Cell Biol 2006;7:446-451.

64). Yang Q, Kardava L, Leger AS, Martincic -K, Varnum-Finney B, Bernstein ID, Milcarek C, Borghesi L E-47 controls the developmental integrity and cell cycle quiescence of multipotential hematopoietic progenitors. J Immunol 2008;181:5885-5894. [PubMed: 18941177]

65). Murre C Helix-loop-helix proteins and lymphocyte development. Nat Immunol 2005; 6:1079_ 1086. [PubMed: 16239924]

66). Jankovic V, Ciarrocchi A, Boccuni P, DeBlasio T, Benezra R, Nimer SD. Id1 restrains myeloid commitment,maintaining the self-renewal capacity of hematopoietic stem cells. Proc Natl acad Sci USA 2007;104:1260-1265. [PubMed: 17227850]

67). Perry SS, Zhao Y, Nie L, Cochrane SW, Huang Z, Sun X. Id1, but not Id3, directs long-term repopulating hematopoietic stem-cell maintenance. Blood 2007;110:2351-2360. [PubMed: 17622570]

68). Suh HC, Ji M, Gooya J, Lee M, Klarmann KD, Keller JR. Cell-nonautonomous function of Id1 in the hematopoietic progenitor cell niche. Blood. 2009; 6;114:1186-11899.

69). Fleming HE, Janzen V, Lo Celso C, Guo J, Leahy KM, Kronemberg HM, Scadden D. Wnt signaling in the niche enforces hematopoietic stem cell quiescence and is necessary to preserve self-renewal in vivo. Cell Stem Cell 2008;2: 274-283. [PubMed: 18371452]

70). Juntilla MM, Patil VD, Calamito M, Joshi RP, Birnbaum MJ, Koretzky GA. AKT1 and AKT2 maintain hematopoietic stem cell function by regulating reactive oxygen species. Blood 2010;115:4030-4038. [PubMed: 20354168]

71). Tzachanis D, Lafuente EM Boussiotis VA. Intrinsic and extrinsic regulation of T lymphocyte quiescence. Leuk Lymphoma 2004;1959-1967. [PubMed: 15370239]

72). Ouyang W, Li MO. Foxo: in command of T-lymphocyte homeostasis and tolerance Trends Immunol 2011;32:26-33.

73). Miyamoto K, Araki KY, Naka K, Arai F, Takubo K, Yamazaki S, Matsuoka S, Miyamoto T, Ito K, Ohmura M, Chen C, Hosokawa K, Nakauchi H, Nakayama K, Nakayama KI, Harada M, Motoyama N, Suda T, Hirao A. Foxo3a is essential for maintenance of the hematopoietic stem cell pool. Cell Stem Cell. 2007;1:101-112. [PubMed: 18371339]

74). Vivanco I, Sawyers CL. The phosphatidylinositol 3-Kinase AKT pathway in human cancer. Nat Rev Cancer 2002;2:489-501. [PubMed: 12094235]

75). Gan B, DePinho RA. mTORC1signaling governs hematopoietic stem cell quiescence Cell cycle 2009;8:1003-6. [PubMed: 19270523]

76). Riedl SJ, Salvesen GS. The apoptosome: signaling platform of cell death. Nat Rev Mol Cell Biol 2007;8:405-413. [PubMed: 17377525]

77). Opferman JT. Life and death during hematopoietic differentiation. Curr Opin Immunol. 2007;19:497-502. [PubMed: 17662585] 
78). Motoyama N, Wang F, Roth KA, Sawa H, Nakayama K, Nakayama K, Negishi I, Senju S, Zhang Q, Fujii S, et al. Massive cell death of immature hematopoietic cells and neurons in Bcl-Xdeficient mice. Science 1995;267:1506-1510. [PubMed: 7878471]

79). Brandt JE, Bhalla K, Hoffman R. Effects of interleukin-3 and c-kit ligand on the survival of various classes of human hematopoietic progenitor cells. Blood 1994;83:1507-1514. [PubMed: 7510143]

80). Keller J R, Ortiz M, Ruscetti FW. Steel Factor (c-kit ligand) promotes the survival of hematopoietic stem/progenitor cells in the absence of cell division. Blood 1995;86:1757-1764. [PubMed: 7544641]

81). Kikushige Y, Yoshimoto G, Miyamoto T, Iino T, Mori Y, Iwasaki H, Niiro H, Takenaka K, Nagafuji K, Harada M, Ishikawa F, Akashi K. Human Flt3 is expressed at the hematopoietic stem cell and the granulocyte/macrophage progenitor stages to maintain cell survival. J Immunol 2008;180:7358-7367. [PubMed: 18490735]

82). Karlsson R, Engström M, Jönsson M, Karlberg P, Pronk CJ, Richter J, Jönsson JI. Phosphatidylinositol 3-kinase is essential for kit ligand-mediated survival, whereas interleukin-3 and flt3 ligand induce expression of antiapoptotic Bcl-2 family genes. J Leukoc Biol 2003;74:923-931. [PubMed: 12960281]

83). Shinjyo T, Kuribara R, Inukai T, Hosoi H, Kinoshita T, Miyajima A, Houghton PJ, Look AT, Ozawa K, Inaba T. Downregulation of Bim, a proapoptotic relative of Bcl-2, is a pivotal step in cytokine-initiated survival signaling in murine hematopoietic progenitors. Mol Cell Biol 2001;21:854-864. [PubMed: 11154272]

84). Kuribara R, Honda H, Matsui H, Shinjyo T, Inukai T, Sugita K, Nakazawa S, Hirai H, Ozawa K, Inaba T. Roles of Bim in apoptosis of normal and Bcr-Abl-expressing hematopoietic progenitors. Mol Cell Biol 2004;24:6172-6183. [PubMed: 15226421]

85). Morris EC, Carrell RW, Coughlin PB. Intracellular serpins in haemopoietic and peripheral blood cells. Br J Haematol 2001;115:758-766. [PubMed: 11843806]

86). Bots M, Medema JP. Serpins in T cell immunity. J Leukoc Biol. 2008;84:1238-1247. [PubMed: 18641264]

87). Byrne S, Aucher A, Alyahya S, Elder M, Olson ST Davis DM, Ashton-Rickardt PG. Cathepsin B controls the persistence of memory CD8+ T lymphocytes. J Immunol. 2012;189:1133-1143. [PubMed: 22745374]

88). Lombard DB, Chua KF,Mostoskavsky R, Franco S, Gostissa m, Alt FW. DNA repair, genome stability, and aging. Cell 2005;120:497-512. [PubMed: 15734682]

89). Liu J, Cao L, Chen J, Song S, Lee IH, Quijano C, Liu H, Keyvanfar K, Chen H, Cao LY, Ahn BH, Kumar NG, Rovira II, Xu XL, van Lohuizen M, Motoyama N, Deng CX, Finkel T. Bmi-1 regulates mitochondrial function and the DNA damage response pathway. Nature 2009;459:387392. [PubMed: 19404261]

90). Wang Y, Kellner J, Liu L, Zhou D. Inhibition of p38 mitogen-activated protein kinase promotes ex vivo hematopoietic stem cell expansion. Stem cells Dev 2011; 20:1143-1152. [PubMed: 21198398]

91). Khaled AR, Moor A N, Li A, Kim K, Ferris DK, Muegge K, Fisher RJ, Fliegel L, Durum SK. Trophic factor withdrawal: p38 mitogen activated kinase activates NHE1, which induces intracellular alkalinization. Mol Cell Biol 2001; 21:7545-7557. [PubMed: 11604491]

92). Shimoio H, Ohtsuka T, Kageyama R. Dynamioc expression of Notch signaling genes in neural stem/progenitor cells. Front Neurosci. 2011;5:78. [PubMed: 21716644]

93). Chiba S. Concise Review: Notch signaling in stem cell systems. Stem Cells 2006;24:2437-3447. [PubMed: 16888285]

94). Li L, Milner LA, Deng Y, Iwata M, Banta A, Graf L, Marcovina S, Friedman C, Trask BJ, Hood L, Torok-Storb B. The human homolog of rat Jagged1 expressed by marrow stroma inhibits differentiation of 32D cells through interaction with Notch1. Immunity 1998;8:43-55. [PubMed: 9462510]

95). Pear WS, Aster JC, Scott ML, Hasserjian RP, Soffer B, Sklar J, Baltimore D. Exclusive development of $\mathrm{T}$ cell neoplasms in mice transplanted with bone marrow expressing activated Notch alleles. J Exp Med 1996;183:2283-2291. [PubMed: 8642337] 
96). Stier S, Cheng T, Dombkowski D, Carlesso N, Scadden DT. Notch1 activation increases hematopoietic stem cell self-renewal in vivo and favors lymphoid over myeloid lineage outcome. Blood 2002;99:2369-2378. [PubMed: 11895769]

97). Duncan AW, Rattis FM, DiMascio LN, Congdon KL, Pazianos G, Zhao C, Yoon K, Cook JM, Willert K, Gaiano N and Reya T. Integration of Notch and Wnt signalling in hematopoietic stem cell maintenance. Nat Immunol 2005;6:314-322. [PubMed: 15665828]

98). Calvi LM, Adams GB, Weibrecht KW, Weber JM, Olson DP, Knight MC, Martin RP, Schipani E, Divieti P, Bringhurst FR, Milner LA, Kronemberg HM, Scadden DT. Osteoblastic cells regulate the hematopoietic stem cell niche. Nature 2003;425:841-846. [PubMed: 14574413]

99). Kim YW, Koo BK, Jeong HW, Yoon MJ, Song R, Shin J, Jeong DC, Kim SH, Kong YY. Defective Notch activation in microenvironment leads to myeloproliferative disease. Blood 2008;112:4628-4638. [PubMed: 18818392]

100). Varnum Finney B, Halasz LM, Sun M, Gridley T, Radtke F, Bernstein ID. Notch2 governs the rate of generation of mouse long-and short term repopulating stem cells. J Clin Invest 2011;121: 1207-1216. [PubMed: 21285514]

101). Butler JM, Nolan DJ, Vertes EL, Varnum Finney B, Kobayashi H, Hooper AT, Seandel E, Shido K, White IA, Kobayashi M, Witte L, May C, Shawber C, Kimura Y, Kitasewski J, Rosenwanks Z, Rafii S. Endothelial cells are essential for the self renewal and repopulation of Notchdependent hematopoietic stem cells. Cell Stem Cell 2010;6:251-264. [PubMed: 20207228]

102). Crotty S, Kaech S, Schoemberger SP. Immunologic Memory in Paul WE Fundamental Immunology, Seventh edition Lippincott William \& Wilkins 2013; 741-764.

103). Sallusto F, Geginat J, Lanzavecchia A. Central memory and effector memory T cell subsets: function, generation and maintenance. Ann Rev Immunol 2004;22:745-763. [PubMed: 15032595]

104). Kassiotis G, Stockinger B. Anatomical heterogeneity of memory CD4+ T cells due to reversible adaptation to the microenvironment. J Immunol 2004;173:7292-7298. [PubMed: 15585852]

105). Tokoyoda K, Zehentmeier S, Hegazy AN, Albrecht I, Grun JR, Lohning M, Radbrunch A. Professional memory CD4+ T lymphocytes preferentially reside and rest in the bone marrow. Immunity 2009;30:721-730. [PubMed: 19427242]

106). Zaph C, Uzonna J, Beverley SM, Scott P. Central memory T cells mediate long-term immunity to Leishmania Major in the absence of persistent parasites Nat Med 2004; 10:1104-1110. [PubMed: 15448686]

107). Macallan DC, Wallace D, Zhang Y, de Lara C, Worth AT, Ghattas H, Griffin GE, Beverley PCL, Tough DF. Rapid turnover of effector-memory CD4+ T cells in healthy humans. J Exp Med 2004;200:255-260. [PubMed: 15249595]

108). Cellerai C, Perreau M, Rozot V, Bellutti Enders F, Pantaleo G, Larari A. Proliferation capacity and cytotoxic activity are mediated by functional and phenotypically distinct virus specific CD8 T cells defined by interleukin-7Ra and perforin expression. J Virol 2010;84:3868:3878. [PubMed: 20130059]

109). Joshi ND, Cui W, Chandele A, Lee HK, Urso DR, Hagman J, Gapin L, Daech SM. Inflammation directs memory precursor and short-lived effector CD8(+) T cell fates via the graded expression of T-bet transcription factor. Immunity 2007;27:281-295. [PubMed: 17723218]

110). Sarkar S, Kalia V, Haining WN, Konieczny BT, Subramaniam S, Ahmed R. Functional and genomic profiling of effector CD8 T cell subsets with distinct memory fates. J Exp Med 2008;205:625-640. [PubMed: 18316415]

111). Wilson DC, Matthews S, Yap GS. IL-12 signaling drives CD8+ T cell IFN-gamma production and differentiation of KLRG1+ effector subpopulations during Toxoplasma Gondii infection J Immunol 2008;180:5935-5945. [PubMed: 18424713]

112). Marshall HD, Chandele H, Jung YW, Meng H, Poholek AC, Parish IA, Rutishauser R, Cui W, Kleinstein SH, Craft J, Kaech SM,. Differential expression of Ly6C and T-Bet distinguish effector andmemory CD4+ cell properties during viral infection. Immunity 2011;35:633-646. [PubMed: 22018471]

113). Qi H, Cannons JL, Klauschen F, Schwartzberg PL, Germain RN. SAP-controlled T-B cell interactions underlie germinal centre formation. Nature 2008;455:764-769. [PubMed: 18843362] 
114). Herndler-Brandstetter D, Landgraf K, Jenewein B, Tzankov A, Brunauer R, Brunner S, Parson W, Kloss F, Gassner R, Lepperdinger G, Grubeck-Loebenstein B. Human bone marrow hosts polyfunctional memory CD4+ and CD8+ T cells with close contact to IL-15- producing cells. J Immunol 2011;186:6965-6971. [PubMed: 21562158]

115). Mazzucchelli RI, Warming S, Lawrence SM, Ishii M, Abshari M, Washington AV, Feigenbaum L, Warner AC, Sims DJ, Li WQ, Hixon JA, Gray DH, Rich BE, Morrow M, Anver MR, Cherry J, Naf D, Sternberg LR, Mc Vicar DW, Farr AG, Germain RN, Rogers K, Jenkins NA, Copeland NG, Durum SK. Visualization and identification of IL-7 producing cells in reporter mice. PLoS One 2009;4:e7637. [PubMed: 19907640]

116). Cerwenka A, Carter LL, Joyce BR, Swain SL, Dutton RW. In vivo persistence of CD8 polarized T cell subsets producing type 1 or type 2 cytokines. J Immunoll998;161:97-105. [PubMed: 9647212]

117). Zhang Y, Joe G, Hexner E, Zhu J, Emerson SG. Host-reactive CD8+ memory stem cells in graftversus-host disease. Nat Med 2005;11:1299-1305. [PubMed: 16288282]

118). Gattinoni L, Zhong XS, Palmer DC, Ji Y, Hinrichs CS, Yu Z, Wrzesinski C, Boni A, Cassard L, Garvin LM, Paulos CM, Muranski P, Restifo NP. Wnt signaling arrests effector T cell differentiation and generates CD8+ memory stem cells. Nature Med 2009;15:808-813. [PubMed: 19525962]

119). Gattinoni L, Lugli E, Pos Z, Paulos C, Quigley MF, Almeida JR, Gostick E, Yu Z, Carpenito C, Wang E, Douek DC, Price D, June CH, Marincola FM, Roederer M, Restifo NP. A human memory T cell subset with stem cell like properties. Nat Med 2011;17:1290-1297. [PubMed: 21926977]

120). Cieri N, Camisa B, Cocchiarella F, Forcato M, Oliveira G, Provasi E, Bondanza A, Bordignon C, Peccatori J, Ciceri F, Lupo-Stanghellini MT, Mavilio F, Mondino A, Bicciato S, Recchia A, Bonini C. IL-7 and IL-15 instruct the generation of human memory stem T cells from naive precursors. Blood 2013; 24;121:573-584.

121). Jiang Q, Li WQ, Aiello FB, Mazzucchelli R, Asefa B, Khaled AR, Durum SK. Cell biology of IL-7, a key lymphotrophin. Cytokine Growth Factor Rev 2005;16:513-533. [PubMed: 15996891]

122). Zhao C and Davies JD. A peripheral CD4+ T cell precursor for naïve, memory, and regulatory $\mathrm{T}$ cells J Exp Med 2010;207:2883-2894. [PubMed: 21149551]

123). Opferman JT, Ober BT, Ashton-Rickardt PG. Linear differentiation of cytotoxic effectors into memory T lymphocytes. Science 1999;283:1745-1748. [PubMed: 10073942]

124). Wherry EJ, Teichgraber V, Becker TC, Masopust D, Kaech SM, Antia R. et al. Lineage relationship and protective immunity of memory CD8 T cell subsets. Nat Immunol 2003;4:225234. [PubMed: 12563257]

125). Harrington LE, Janowski KM, Oliver JR, Zajac AJ, Weaver CT. Memory CD4 T cells emerge from effector T-cell progenitors. Nature 2008;452:356. [PubMed: 18322463]

126). Bannard O, Kraman M, Fearon DT. The secondary replicative function of CD8+ T cells that expressed granzyme B during a primary anti-viral response. Science 2009;323:505-509. [PubMed: 19164749]

127). Stemberger C, Huster KM, Koffler M, Anderl F, Schiemann M, Wagner H, Busch DH. A single naïve CD8(+) T cell precursor can develop into diverse effector and memory subsets. Immunity 2007;27:985-997. [PubMed: 18082432]

128). Chang JT, Palanivel VR, Kinjyo I, Schambach F, Intlekofer AM, Banerjee A, Longworth SA, Vinup KE, Mrass P, Oliaro J, Killeen N, Orange JS, Russel SM, Weninger W, Reiner SL. Asymmetric T lymphocyte division in the initiation of adaptive immune responses. Science 2007;315:1687-1691. [PubMed: 17332376]

129). Laouar AM, Manocha M, Haridas V, Manjunath N. Concurrent generation of effector and central memory CD8 T cells during vaccinia virus infection. Plos One 2008;3:e4089. [PubMed: 19116651]

130). Teixeiro E, Daniels MA, Hamilton SE, Schrum A, Bragado R, Jameson SC, Palmer E. Different $\mathrm{T}$ cell receptor signals determine CD8+ memory versus effector development. Science 2009;323:502-505. [PubMed: 19164748] 
131). Reiner SL, Sallusto F, Lanzavecchia A. Division of labor with a workforce of one: challenges in specifying effector and memory T cell fate. Science 2007;317:622-625. [PubMed: 17673652]

132). Catron DM, Rusch LK, Hataye J, Itano AA, Jenkins MK. CD4+ T cells that enter the draining lymph nodes after antigen injection participate in the primary response and became centralmemory cells. J Exp Med 2006;203:1045-1054. [PubMed: 16567390]

133). D'Souza WN, Hedrick SM. Cutting edge: latecomer CD8 T cells are imprinted with a unique differentiation program. J Immunol 2006;177:777-781. [PubMed: 16818730]

134). Ciocca C, Barnett BE, Burkhardt JK, Chang JT, Reiner SL. Cutting edge: Asymmetric memory T cell division in response to rechallenge. J Immunol 2012;188:4145-4148. [PubMed: 22467651]

135). Glimcher LH, Towsend MJ, Sullivan MS, Lord GM. Recent developments in the transcriptional regulation of cytolytic effector cells. Nat Rev Immunol 2004;4:900-911. [PubMed: 15516969]

136). Xue H, Zhao DM. Regulation of mature T cell response by the Wnt signaling pathway. Ann N Y Acad Sci 2012;1247:16-33. [PubMed: 22239649]

137). Willinger T, Freeman T, Herbert M, Hasegawa H, McMichael AJ, Callan MFC. Human naïve CD8 T cells down-regulate expression of the WNT pathway transcription factors lymphoid enhancer binding factor 1 and transcription factor 7 (T cell factor-1) following antigen encounter in vitro and in vivo. J Immunol 2006;176:1439-1446. [PubMed: 16424171]

138). Zhou X, Yu S, Zhao DM, Harty JT, Badovinac VP, Xue H. Differentiation and persistence of CD8+ cells depend on T cell factor 1. Immunity 2010;33:229-240. [PubMed: 20727791]

139). Prlic M, Bevan MJ. $\beta$-catenin is dispensable for T cell effector differentiation, memory formation and recall responses. J Immunol 2011;187:1542-1546. [PubMed: 21724993]

140). Driessens G, Zheng Y, Gajewski TF. $\beta$-catenin does not regulate memory T cell phenotype. Nat Med 2010;16:513-514. [PubMed: 20448567]

141). Muranski P, Borman ZA, Kerkar SP, Klebanoff CA, Ji Y, Sanchez-Perez L, Sukumar M, Reger RN, Yu Z, Kern SJ, Roychoudhuri R, Ferreyra GA, Shen W, Durum SK, Feigenbaum L, Palmer DC, Antony PA, Chan CC, Laurence A, Danner RL, Gattinoni L, Restifo NP. Th17 cells are long lived and retain a stem cell-like molecular signature. Immunity 2011;35:972-985. [PubMed: 22177921]

142). Pepper M, Linehan JL, Pagán AJ, Zell T, Dileepan T, Cleary PP, Jenkins MK. Different routes of bacterial infection induce long-lived TH1 memory cells and short-lived TH17 cells. Nat Immunol. 2010;11:83-89. [PubMed: 19935657]

143). Kryczek I, Zhao E, Liu Y, Wang Y, Vatan L, Szeliga W, Moyer J, Klimczak A, Lange A, Zou W. Human TH17 cells are long-lived effector memory cells. Sci Transl Med. 2011;3:104ral00.

144). Hu Y, Shen F, Crellin NK, Ouyang W. The IL-17 pathway as a major therapeutic target in autoimmune diseases. Ann NY Acad Sci. 2011;1217:60-76. [PubMed: 21155836]

145). Rao RR, Li Q, Gubbels Bupp MR, Srikant PA. Transcription factor Foxo1 represses Tbetmediated effector functions and promotes memory CD8+ T cell differentiation. Immunity 2012;36:374-387. [PubMed: 22425248]

146). Araki K, Turner AP, Shaffer VO, Gangappa S, Keller SA, Bachmann MF, Larsen CP, Ahmed R. mTOR regulates memory CD8 T-cell differentiation. Nature 2009;460:108-112. [PubMed: 19543266]

147). Kim EH, Sullivan JA, Plisch EH, Tejera MM, Jatzek A, Choi KY, Suresh M. Signal integration by Akt regulates CD8 T cell effector and memory differentiation. J Immunol. 20125 1;188:4305-4314. [PubMed: 22467649]

148). Cannarile MA, Lind NA, Rivera R, Sheridan AD, Camfield KA, Wu BB, Cheung KP, Ding Z, Goldrath AW. Transcripional regulator ld2 mediates CD8+ T cell immunity. Nat Immunol 2006;7:1317-1325. [PubMed: 17086188]

149). Yang CY, Best AJ, Knell J, Yang E, Sheridan ADR, Jesionek AK, Li HS, Rivera RR, Lind KC, D'Cruz LM, Watowich SS, Murre C, Goldrath AW. The transcriptional regulators Id2 and Id3 control the formation of distinct memory T cell subsets. Nat Immunol 2011; 12:1221-1229. [PubMed: 22057289]

150). Ji Y, Pos Z, Rao M, Klebanoff CA, Yu Z, Madhusudhanan S, Reger RN, Palmer DC, Borman ZA, Muranski P, Wang E, Schrump DS, Marincola FM, Restifo NP, Gattinoni L.Repression of 
the DNA-binding inhibitor Id3 by Blimp-1 limits T cell memory formation. Nat Immunol 2011;12:1230-1237. [PubMed: 22057288]

151). Fukuda T, Miki T, Yoshida T, Hatano M, Ohashi K, Hirosawa S. Tokuhisa T. The murine Bcl-6 gene is induced in activated lymphocytes as an immeadiate early gene. Oncogene 1995;11:16571663. [PubMed: 7478591]

152). Rutishauser RL, Martins GA, Kalachikov S, Chandele A, Parish IA, Meffre E, Jacob J, Calame K, Kaech SM. Transcriptional repressor Blimp-1 promotes CD8(+) T cell terminal differentiation and represses the acquisition of central memory T cell properties. Immunity 2009;31:296-308. [PubMed: 19664941]

153). Kallies A, Xin A, Belz GT, Nutt SL. Blimp-1 transcription factor is required for the differentiation of effector CD8+ T cells and memory responses. Immunity. 2009;31:283-295. [PubMed: 19664942]

154). Yajima T, Yoshihara K, Nakazato K, Kumabe S, Koyasu S, Sad S, Shen H, Kuwano H, Yoshikai Y. IL-15 regulates CD8+ T cell contraction during primary infection J Immunol 2006;176:507515. [PubMed: 16365444]

155). Williams MA, Tyznik AJ, Bevan MJ. Interleukin-2 signals during priming are required for secondary expansion of CD8+ memory T cells. Nature 2006;441:890-893. [PubMed: 16778891]

156). Dooms H, Wolslegel K, Lin P, Abbas AK. Interleukin-2 enhances CD4+ T cell memory by promoting the generation of IL-7R alpha-expressing cells. J Exp Med 2007;204:547-557. [PubMed: 17312008]

157). Foulds KE, Rotte MJ, Seder RA.IL-10 is required for optimal CD8 T cell memory following Listeria monocytogenes infection. J Immunol 2006;177:2565-2574. [PubMed: 16888018]

158). Biswas PS, Pedicord V, Ploss A, Menet E, Leiner I, Pamer EG. Pathogen-specificCD8 T cell responses are directly inhibited by IL-10. J Immunol. 2007;179 4520-4528.

159). Cui W, Liu Y, Weinstein JS, Craft J, Kaech SM. An interleukin-21-interleukin-10-STAT3 pathway is critical for functional maturation of memory CD8+ T cells. Immunity 2011;35:792805. [PubMed: 22118527]

160). Surh CD, Sprent J. Homeostasis of naive and memory T cells. Immunity 2008;29:848-862. [PubMed: 19100699]

161). Cheung KP, Yang E, Goldrath AW. Memory-like CD8+ T cells generated during homeostatic proliferation defer to antigen-experienced memory cells. J Immunol 2009;183:3364-3372. [PubMed: 19675163]

162). Li Q, Rao RR, Araki K, Pollizzi K, Odunsi K, Powell JD, Shrikant PA. A central role for mTOR kinase in homeostatic proliferation induced CD8+ T cell memory and tumor immunity. Immunity 2011;34:541-553. [PubMed: 21511183]

163). Ichii H, Sakamoto A, Arima M, Hatano M, Kuroda Y, Tokuhisa T. Bcl6 isessential for the generation of long-term memory CD4+ T cells. Int Immunol 2007;19:427-433. [PubMed: 17307796]

164). Heffner M, Fearon DT. Loss of T cell receptor-induced Bmi-1 in the KLRG1(+) senescent CD8(+) T lymphocyte. Proc Natl Acad Sci U S A 2007;104:13414-13419. [PubMed: 17686974]

165). Schaller MA, Logue H, Mukherjee S, Lindell DM, Coelho AL, Lincoln P, Carson WF, 4th, Ito T, Cavassani KA, Chensue SW, Hogaboam CM, Lukacs NW, Kunkel SL. Delta-like 4 differentially regulates murine CD4 T cell expansion via BMI1. Plos One 2010;5:e12172. [PubMed: 20808960]

166). Yi JS, Cox MA, Zajac AJ. T-cell exhaustion: characteristics, causes and conversion. Immunology 2010;129:474-481. [PubMed: 20201977]

167). Plunkett FJ, Franzese O, Belaramani LL, Fletcher JM, Gilmour KC, Sharifi R, Khan N, Hislop AD, Cara A, Salmon M, Gaspar HB, Rustin MH, Webster D, Akbar AN. The impact of telomere erosion on memory CD8+ T cells in patients with X-linked lymphoproliferative syndrome. Mech Ageing Dev 2005;126:855-865. [PubMed: 15992610]

168). Wong WF, Kohu K, Nakamura A, Ebina M, Kikuchi T, Tazawa R, Tanaka K, Kon S, Funaki T, Sugahara-Tobinai A, Looi CY, Endo S, Funayama R, Kurokawa M, Habu S, Ishii N, Fukumoto M, Nakata K, Takai T, Satake M. Runx1 deficiency in CD4+ T cells causes fatal autoimmune 
inflammatory lung disease due to spontaneous hyperactivation of cells. J Immunol 2012;188:5408-5420. [PubMed: 22551552]

169). Corvol JC, Pelletier D, Henry RG, Caillier SJ, Wang J, Pappas D, Casazza S, Okuda DT, Hauser SL, Oksenberg JR, Baranzini SE. Abrogation of T cell quiescence characterizes patients at high risk for multiple sclerosis after the initial neurological event. Proc Natl Acad Sci U S A 2008;105:11839-11844. [PubMed: 18689680]

170). Rawlings JS, Gatzka M, Thomas PG, Ihle JN. Chromatin condensation via the condensin II complex is required for peripheral T-cell quiescence. Embo J 2011;30:263-276. [PubMed: 21169989]

171). Hamilton SE, Jameson SC. CD8 T cell quiescence revisited. Trends Immunol 2012;33:224-230. [PubMed: 22361353]

172). Allam A, Conze DB, Giardino Torchia ML, Munitic I, Yagita H, Sowell RT, Marzo AL, Ashwell JD. The CD8+ memory T-cell state of readiness is actively maintained and reversible. Blood 2009;114:2121-2130. [PubMed: 19617575]

173). Aiello FB, Keller JR, Klarmann KD, Dranoff G, Mazzucchelli R, Durum SK. IL-7 induces myelopoiesis and erythropoiesis. J Immunol 2007;178:1553-1563. [PubMed: 17237404]

174). Dalai SK, Khoruzhenko S, Drake CG, Jie CC, Sadegh-Nasseri S. Resolution of infection promotes a state of dormancy and long survival of CD4 memory T cells. Immunol Cell Biol 2011;89: 870-881. [PubMed: 21358746]

175). Dzhagalov I, Dunkle A, He YW. The anti-apoptotic Bcl-2 family member Mcl-1 promotes T lymphocyte survival at multiple stages. J Immunol 2008;181:521-528. [PubMed: 18566418]

176). Dunkle A, Dzhagalov I, He YW. Cytokine-dependent and cytokine-independent roles for Mcl-1: genetic evidence for multiple mechanisms by which Mcl-1 promotes survival in primary $\mathrm{T}$ lymphocytes. Cell Death Dis 2011;2,e214. [PubMed: 21975296]

177). Chetoui N, Boisvert M, Gendron, Aoudjit F. Interleukin-7 promotes the survival of human CD4+ effector memory T cells up-regulating Bcl-2 proteins and activating the Jak/Stat signalling pathway. Immunology 2010;120:418-426.

178). Yao Z, Cui Y, Watford WT, Bream JH, Yamaoka K, Hissong BD, Li D, Durum SK, Jiang Q, Bhandoola A, Hennighausen L, O'Shea JJ. Stat5a/b are essential for normal lymphoid development and differentiation. Proc Natl Acad Sci U S A 2006;103:1000-1005. [PubMed: 16418296]

179). Hand TW, Cui W, Jung YW, Sefik E, Joshi NS, Chandele A, Liu Y, Kaech SM. Differential effects of STAT5 and PI3K/AKT signaling on effector and memory CD8 T-cell survival. Proc Natl Acad Sci U S A 2010;107:16601-1666. [PubMed: 20823247]

180). Kibe R, Zhang S, Guo D, Marrero L, Tsien F, Rodriguez P, Khan S, Zieske A, Huang J, Li W, Durum SK, Iwakuma T, Cui Y. IL-7R \pm deficiency in p53null mice exacerbates thymocyte telomere erosion and lymphomagenesis. Cell Death Differ 2012; 19:1139-1151 [PubMed: 22281704]

181). Nakazato K, Yamada H, Yajima T, Kagimoto Y, Kuwano H, Yoshikai Y. Enforced expression of Bcl-2 partially restores cell numbers but not functions of TCRgammadelta intestinal intraepithelial T lymphocytes in IL-15-deficient mice. J Immunol 2007;178:757-764. [PubMed: 17202336]

182). Sabbagh L, Srokowski CC, Pulle G, Snell LM, Sedgmen BJ, Liu Y, Tsitsikov EN, Watts TH. A critical role for TNF receptor-associated factor 1 and Bim down-regulation in CD8 memory T cell survival. Proc Natl Acad Sci U S A 2006;103:18703-18708. [PubMed: 17116875]

183). Huntington ND, Puthalakath H, Gunn P, Naik E, Michalak EM, Smyth MJ, Tabarias H, DegliEsposti MA, Dewson G, Willis SN, Motoyama N, Huang DC, Nutt SL, Tarlinton DM, Strasser A. Interleukin 15-mediated survival of natural killer cells is determined by interactions among Bim, Noxa and Mcl-1. Nat Immunol 2007;8:856-863. [PubMed: 17618288]

184). Sullivan JA,Kim EH, Plisch EH, Peng SL, Suresh M. Foxo3 regulates CD8 T cell memory by T cell-intrinsic mechanisms. Plos Pathog 2012;86:9025-9034.

185). Van Der Heide LP, Hoekman MFM, Smidt MP. The ins and outs of FoxO shuttling. Mechanisms of FoxO translocation and transcriptional regulation. Biochem J. 2004;380:297-309. [PubMed: 15005655] 
186). Riou C, Yassin-Di ab, Van Grevenynghe J, Somogyi R, Greller LD, Gagnon D, Gimmig S, Wilkinson p, Shi Y, Cameron MJ, Campos-Gonzales R, Balderas RS, Kelvin D, Sekaly RP, Haddad KL. Convergence of TCR and cytokine signalling leads to FoxO3a phosphorylation and drives the survival of CD4+ central memory T cells. J Exp Med 2007;204:79-91. [PubMed: 17190839]

187). Zhang M, Byrne S, Liu N, Wang Y, Oxenius A, Ashton-Rickardt PG. Differential survival of cytotoxic T cells and memory cell precursors. J Immunol 2007;178:3483-3491. [PubMed: 17339443]

188). Arlt A, Schäfer H. Role of the immediate early response 3 (IER3) gene in cellular stress response, inflammation and tumorigenesis. Eur J Cell Biol 2011;90:545-552. [PubMed: 21112119]

189). Zhang Y, Schlossman SF, Edwards RA, Ou CN, Gu J, Wu MX. Impaired apoptosis, extended duration of immune responses, and a lupus-like autoimmune disease in IEX-1-transgenic mice. Proc Natl Acad Sci U S A. 2002;99:878-883. [PubMed: 11782530]

190). Zhi L, Ustyugova IV, Chen X, Zhang Q, Wu MX. Enhanced Th17 differentiation and aggravated arthritis in IEX-1-deficient mice by mitochondrial reactive oxygen species-mediated signaling. $\mathrm{J}$ Immunol 2012;189:1639-1647. [PubMed: 22798682]

191). Ott M, Gogvadze V, Orrenius S, Zhivotovsky B. Mitochondria, oxidative stress and cell death. Apoptosis 2007;12:913-922. [PubMed: 17453160]

192). Shen L, Zhi L, Hu W, Wu MX. IEX-1 targets mitochondrial F1Fo-ATPase inhibitor for degradation. Cell Death Differ. 2009;16:603-612. [PubMed: 19096392]

193). Yoon S, Ha HJ, Kim YH, Won M, Park M, Ko JJ, Lee K, Bae J. IEX-1-induced cell death requires BIM and is modulated by MCL-1 Biochem Biophys Res Commun 2009;382:400-404. [PubMed: 19285955]

194). Pawlinowska P, Leray I, de Laval B, Guihard S, Kumar R, Rosselli F, Porteu F. ATM-dependent expression of IEX-1 controls nuclear accumulation of Mcl-1 and the DNA damage response. Cell Death Differ 2010;17:1739-1750. [PubMed: 20467439]

195). Prall WC, Czibere A, Grall F, Spentzos D, Steidl U, Giagounidis AA, Kuendgen A, Otu H, Rong A, Libermann TA, Germing U, Gattermann N, Haas R, Aivado M. Differential gene expression of bone marrow-derived CD34+ cells is associated with survival of patients suffering from myelodysplastic syndrome. Int J Hematol 2009;89:173-187 [PubMed: 19152102]

196). Steensma DP, Neiger JD, Porcher JC, Keats JJ, Bergsagel PL, Dennis TR, Knudson RA, Jenkins RB, Santana-Davila R, Kumar R, Ketterling RP. Rearrangements and amplification of IER3 (IEX-1) represent a novel and recurrent molecular abnormality in myelodysplastic syndromes. Cancer Res 2009;69:7518-7523. [PubMed: 19773435]

197). Yamashita M, Kuwahara M, Suzuki A, Hirahara K, Shinnaksu R, Hosokawa H, Hasegawa A, Motohashi S, Iwama A, Nakayama T. Bmi-1 regulates memory CD4 T cell survival via repression of the Noxa gene. J Exp Med 2008;205:1109-1120. [PubMed: 18411339]

198). Wilson CB, Ro atol. well E, Sekimata M. Epigenetic control of T-helper-cell differentiation. Nature Rev Immunol 2009;9:91-105. [PubMed: 19151746]

199). Pai SY, Truitt ML, Ho IC. GATA-3 deficiency abrogates the development and maintenance of T helper type 2 cells. Proc Natl Acad Sci U S A. 2004;101:1993-1998. [PubMed: 14769923]

200). Zhu J, Min B, Hu-Li J, Watson CJ, Grinberg A, Wang Q, Killeen N, Urban JF, Jr, Guo L, Paul WE. Conditional deletion of Gata3 shows its essential function in $\mathrm{T}(\mathrm{H}) 1-\mathrm{T}(\mathrm{H}) 2$ responses. Nat Immunol 2004;5:1157-1165. [PubMed: 15475959]

201). Avni O, Lee D, Macian F, Szabo JJ, Glimcher LH, Rao A. TH differentiation is accompanied by dynamic changes in histone acetylation of cytokine genes. Nat Immunol 2002;4:643-651.

202). Yamashita M, Ukai-Tadenuma M, Miyamoto T, Sugaya K, Hosokawa H, Hasegawa A, Kimura M, Taniguchi M, DeGregori J, Nakayama T. Essential role of GATA3 for the maintenance of type 2 helper T (Th2) cytokine production and chromatin remodelling at the Th2 cytokine gene loci. J Biol Chem 2004;279:26983-26990. [PubMed: 15087456]

203). Yamashita M, Shinnakasu R, Nigo Y, Kimura M, Hasegawa A, Taniguchi M, Nakayama T. Interleukin (IL)-4-independent maintenance of histone modification of the IL-4 gene loci in memory Th2 cells. J Biol Chem 2004;279:39454-3964. [PubMed: 15258154] 
204). Milne TA, Briggs SD, Brock HW, Martin ME, Gibbs D, Allis CD, Hess JL. MLL targets SET domain methyltransferase activity to Hox gene promoters. Mol Cell 2002;10:1107-1117. [PubMed: 12453418]

205). Asnagli H, Afkarian M, Murphy KM. Cutting edge: Identification of an alternative GATA-3 promoter directing tissue-specific gene expression in mouse and human. $\mathrm{J}$ Immunol 2002;168:4268-4271. [PubMed: 11970965]

206). Onodera A, Yamashita M, Endo Y, Kuwahara M, Tofukuji S, Hosokawa H, Kanai A, Suzuki Y, Nakayama T. STAT6-mediated displacement of polycomb by trithorax complex establishes longterm maintenance of GATA3 expression in T helper type 2 cells J Exp Med 2010;207:24932506. [PubMed: 20956546]

207). Guru SC, Manickam P, Crabtree JS, Olufemi SE, Agarwal SK, Debelenko LV. Identification and characterization of the multiple endocrine neoplasia type 1 (MEN1) gene. J Intern Med 1998;243:433-439. [PubMed: 9681840]

208). Yamashita M, Hirahara K, Shinnakasu R, Hosokawa H, Norikane S, Kimura MY, Hasegawa A, Nakayama T. Crucial role of MLL for the maintenance of memory T helper type 2 cell responses. Immunity 2006;24:611-622. [PubMed: 16713978]

209). Nakata Y, Brignier AC, Jin S, Shen Y, Rudnick SI, Sugita M, Gewirtz AM. c-Myb, Menin, GATA-3, and MLL form a dynamic transcription complex that plays a pivotal role in human T helper type 2 cell development. Blood 2010;116:1280-1290. [PubMed: 20484083]

210). Ouyang W, Löhning M, Gao Z, Assenmacher M, Ranganath S, Radbruch A, Murphy KM. Stat6independent GATA-3 autoactivation directs IL-4-independent Th2 development and commitment. Immunity 2000;12:27-37. [PubMed: 10661403]

211). Maurice D, Hooper J, Lang G, Weston K. c-Myb regulates lineage choice indeveloping thymocytes via its target gene Gata3. Embo J 2007;26:3629-3640. [PubMed: 17641686]

212). Wang P, Lin C, Smith ER, Guo H, Sanderson BW, Wu M, Gogol M, Alexander T, Seidel C, Wiedemann LM, Ge K, Krumlauf R, Shilatifard A. Global analysis of H3K4 methylation defines MLL family member targets and points to a role for MLL1-mediated H3K4 methylation in the regulation of transcriptional initiation by RNA polymerase II. Mol Cell Biol 2009;29:6074-6085. [PubMed: 19703992]

213). Akasaka T, Tsuji K, Kawahira H, Kanno M, Harigaya K, Hu L, Ebiwara Y, Nakahata T, Tetsu O, Taniguchi M, Koseki H. The role for Mel 18, a polycomb group gene, during IL-7- dependent proliferation of lymphocyte precursors. Immunity 1997;7:1135-1146.

214). Kimura M, Koseki Y, Yamashita M, Watanabe N, Shimizu C, Katsumoto T, Kitamura T, Taniguchi M, Koseki H, Nakayama T. Regulation of Th2 cell differentiation by Mel-18, a mammalian polycom group gene. Immunity 2001;15:275-287. [PubMed: 11520462]

215). Jacob E, Hod-Dvorai R, Ben-Mordechai OL, Boyko Y, Avni O. Dual function ofpolycomb group proteins in differentiated murine T helper (CD4+) cells. J Mol Signal 2011;6:5. [PubMed: 21624129]

216). Caré A, Testa U, Bassani A, Tritarelli E, Montesoro E, Samoggia P, Cianetti L, Peschle C. Coordinate expression and proliferative role of HOXB genes in activated adult T lymphocytes. Mol Cell Biol. 1994;14:4872-4877. [PubMed: 7911974]

217). Morgan R, Whiting K. Differential expression of HOX genes upon activation of leukocyte subpopulations. Int J Hematol 2008;87:246-249. [PubMed: 18317880]

218). Rothenberg E, Zhang JA. T-cell identity and epigenetic memory. T-cell identity and epigenetic memory. Curr Top Microbiol Immunol 2012;356:117-143. [PubMed: 21833836] 
Long-term murine HSC

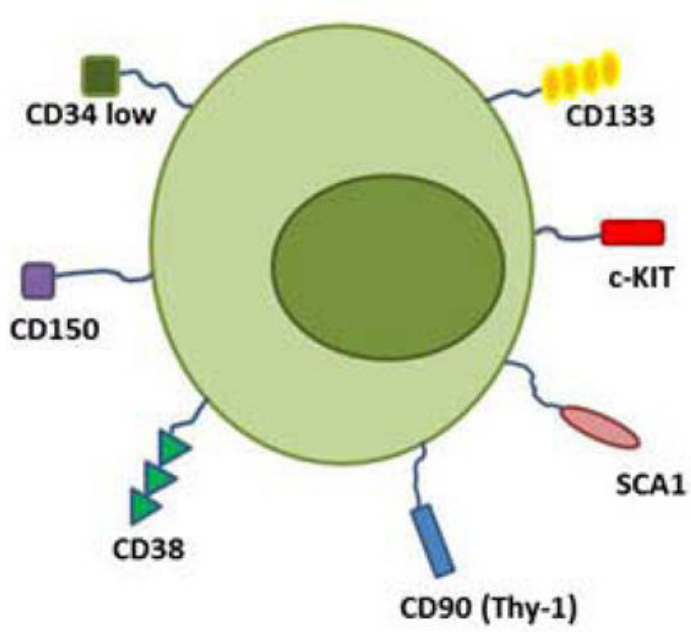

Long-term human HSC

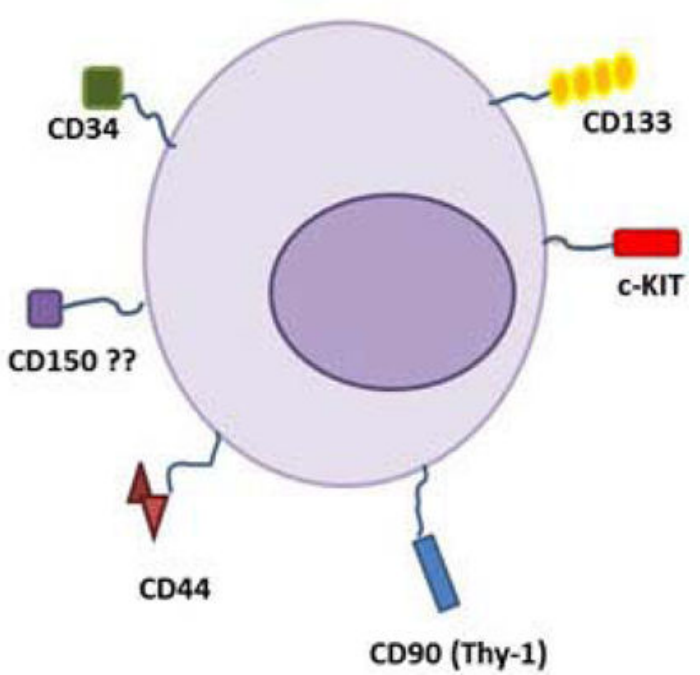

Fig. 1. Markers of murine and human hematopoietic stem cells.

Specific markers permit the purification of long-term hematopoietic stem cells which represent less than $0.5 \%$ of bone marrow cells. The presence of CD150 and CD38 on murine cells greatly facilitates their purification. 


\section{Murine T memory stem cells}

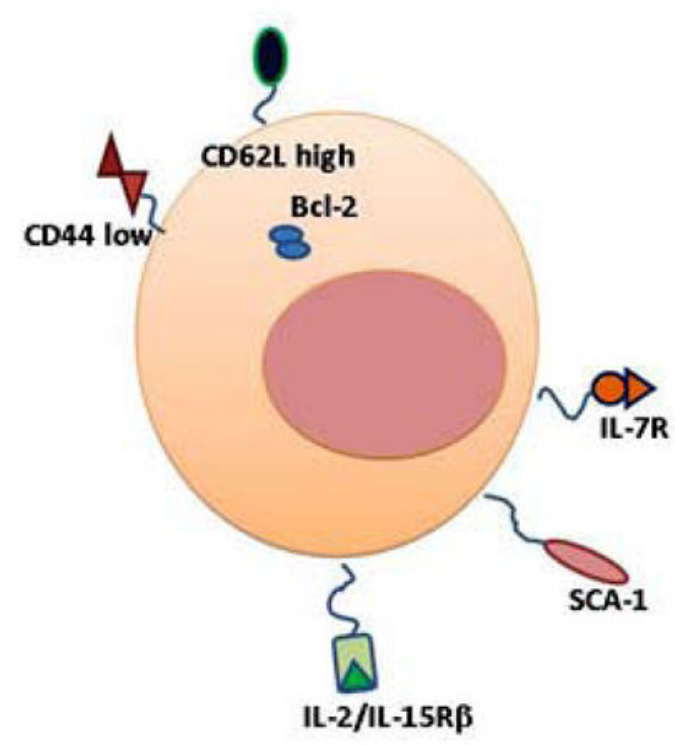

Human T memory stem cells

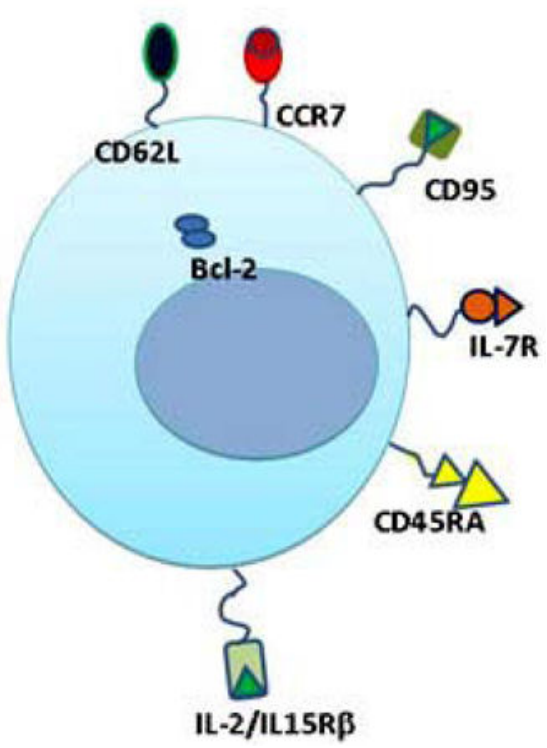

Fig. 2. Markers of murine and human memory $T$ cells characterized by high self renewal capacity.

This illustration describes cells defined as "T memory stem cells" according to References [118], [119]. These cells are generated by activating the Wnt pathway during the priming phase. They are long-lived, display robust proliferative and effector capacities. Murine cells are able to reconstitute an effective immune response in immunodeficient hosts. They express low levels of CD44 in mice and high levels of CD45RA in humans. 

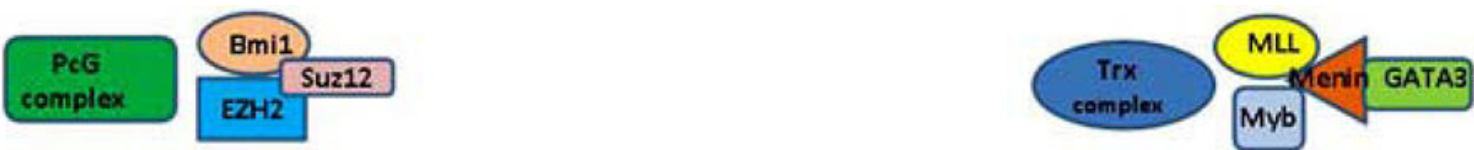

GATA3 locus

Distal promoter 1a

Proximal promoter $1 \mathrm{~b}$

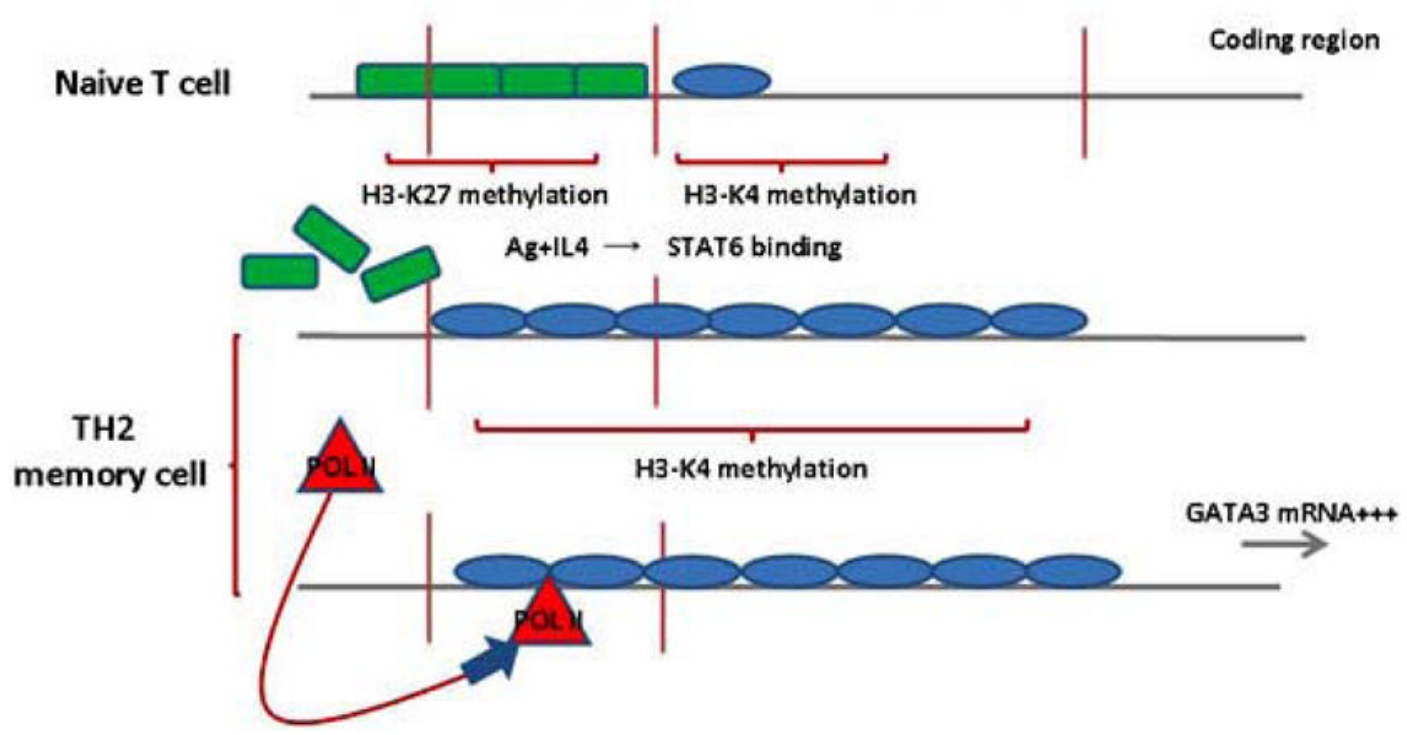

Fig. 3. Maintenance of GATA3 mRNA transcription in TH2 memory cells.

Schematic representation of the transcriptional regulation of the GATA 3 gene in memory TH2 cells according to References 206 and 209. After the development of TH2 cells, the Trithorax complex binds to the whole GATA3 gene, inducing an open chromatin status that maintains high expression of GATA3 mRNA in the absence of IL-4. 
Table 1.

Self-renewal regulators for hematopoietic stem cells

\begin{tabular}{|c|c|c|}
\hline FUNCTION & SELF-RENEWAL REGULATOR ${ }^{1}$ & REFERENCE \\
\hline \multirow[t]{9}{*}{ Proliferation } & Hox family & $10,29,30$ \\
\hline & Bmi-1 & $10,31,32$ \\
\hline & Mel-18* & 35 \\
\hline & MLL & $38-40$ \\
\hline & Notch family members & $12,41,93$ \\
\hline & Wnt3A & $46,48,52$ \\
\hline & SCF & 55,56 \\
\hline & Stat3, Stat5 & $55-57$ \\
\hline & IL-10 & 58 \\
\hline \multirow[t]{11}{*}{ Quiescence } & MLL & 39,40 \\
\hline & $\mathrm{p}-21$ & 61,62 \\
\hline & Gfi-1 & 61 \\
\hline & E47 & 61,64 \\
\hline & Id-1 & $66-68$ \\
\hline & Wnt & 52,69 \\
\hline & $\mathrm{AKT}^{*}$ & 70 \\
\hline & pten & 61,74 \\
\hline & FoxO3a & 73 \\
\hline & p38MAPK* & 73 \\
\hline & mTORC1* & 75 \\
\hline \multirow[t]{8}{*}{ Survival } & $\mathrm{SCF}$ & $56,79,80$ \\
\hline & IL-3 & $79,82,83$ \\
\hline & IL-6 & 81 \\
\hline & Flt3-ligand & 81,82 \\
\hline & Bcl-2 family & $77-78$ \\
\hline & Bim* & 83,84 \\
\hline & Serpins & 85 \\
\hline & Bmi-1 & 89 \\
\hline Maintenance of identity & Notch & $94,96,97,98-100$ \\
\hline
\end{tabular}


Table 2.

Self-renewal regulators for memory $\mathrm{T}$ lymphocytes

\begin{tabular}{|c|c|c|}
\hline FUNCTION & SELF-RENEWAL REGULATOR ${ }^{1}$ & REFERENCE \\
\hline \multirow[t]{6}{*}{ Proliferation } & IL-7, IL-15 & $102,120,121,160-161$ \\
\hline & mTOR & 162 \\
\hline & Bcl-6 & $9,159,163$ \\
\hline & Stat3 & 159 \\
\hline & Stat5 & 179 \\
\hline & Bmi-1 & 164,165 \\
\hline \multirow[t]{2}{*}{ Quiescence } & SLAM & 167 \\
\hline & FoxO1 & 172 \\
\hline \multirow[t]{8}{*}{ Survival } & IL-7, IL-15 & $121,176,180,181$ \\
\hline & Bcl-2 family members & $121,175,176,181$ \\
\hline & Stat5 & $121,178,179$ \\
\hline & Bim* & $182-184$ \\
\hline & FoxO3 & 185,186 \\
\hline & Serpins (Spi2A, Spi6) & $86,87,187$ \\
\hline & Iex-1 & 189,190 \\
\hline & Bmi-1 & 197 \\
\hline \multirow[t]{5}{*}{ Maintenance of identity } & GATA3 & 202, 203, 206, 209 \\
\hline & MLL & 203, 204, 208, 204 \\
\hline & Menin & 206,209 \\
\hline & $\mathrm{cMyb}$ & 209 \\
\hline & Polycomb family & $213-215$ \\
\hline
\end{tabular}

${ }^{1}$ Asterisks indicate negative regulation. 